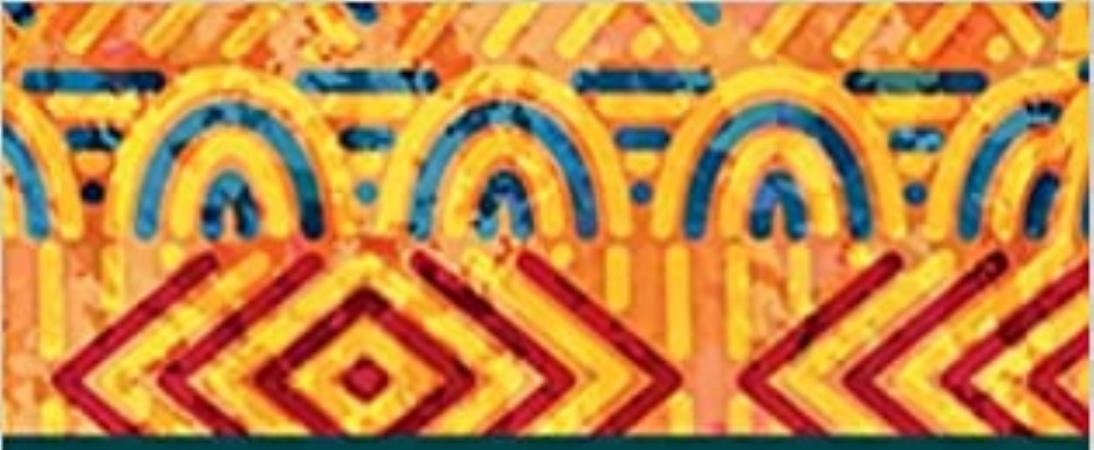

\title{
Key Texts for \\ Latin American \\ Sociology
}

tdited by Fernanda Beigel 
Key Texts for Latin American Sociology 


\section{SAGE STUDIES IN}

\section{INTERNATIONAL SOCIOLOGY}

Series Editor Chaime Marcuello Servós (2016-ongoing)

Editor, Department of Psychology and Sociology,

Zaragoza University, Spain

\section{RECENT BOOKS IN SERIES}

Global Sociology and the Struggles for a Better World: Towards the Futures We Want

Edited by Markus S. Schulz

Sociology and Social Justice

Edited by Margaret Abraham 


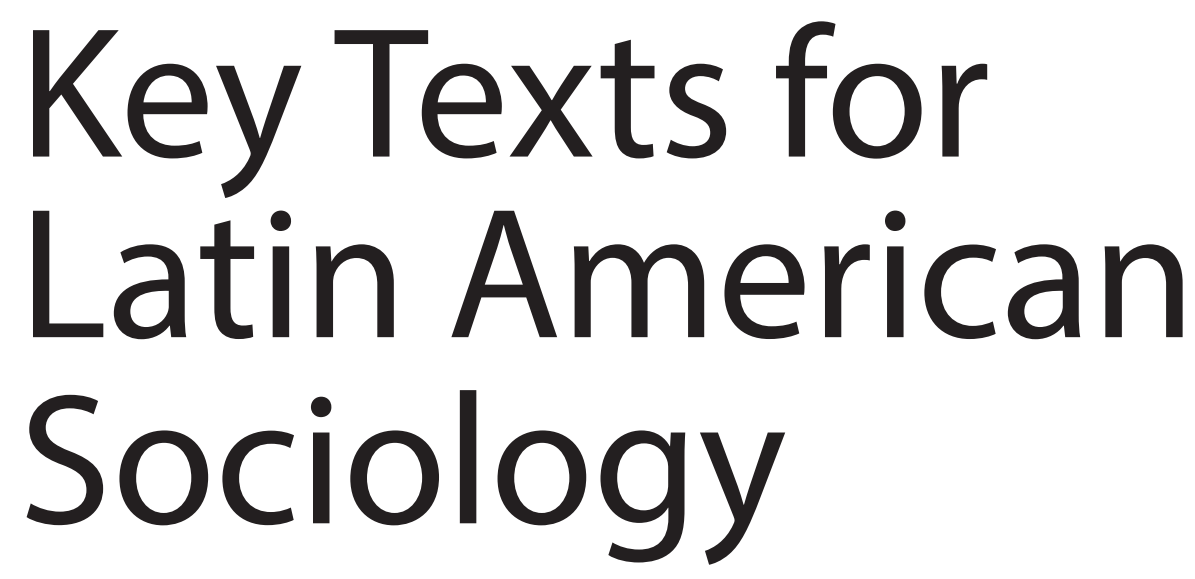

Edited by Fernanda Beigel 


\section{(9SAGE}

Los Angeles | London | New Delhi

Singapore | Washington DC | Melbourne

SAGE Publications Ltd

1 Oliver's Yard

55 City Road

London EC1Y 1SP

SAGE Publications Inc.

2455 Teller Road

Thousand Oaks, California 91320

SAGE Publications India Pvt Ltd

B 1/l 1 Mohan Cooperative Industrial Area

Mathura Road

New Delhi 110044

SAGE Publications Asia-Pacific Pte Ltd

3 Church Street

\#10-04 Samsung Hub

Singapore 049483

Editor: Natalie Aguilera

Assistant Editor: Eve Williams

Production editor: Katherine Haw

Copyeditor: Rosemary Campbell

Indexer: Elizabeth Ball

Marketing manager: George Kimble

Cover design: Wendy Scott

Typeset by: C\&M Digitals (P) Ltd, Chennai, India

Printed in the UK
Introductory Study @ Fernanda Beigel 2019

Chapter 1 @ Jorge Rovira Mas 2019

Chapter 2 ( Alberto Guerreiro Ramos 2019. Authorized by Alberto

Guerreiro Ramos's son and archive rights administrator; Comment (C) João Maia 2019

Chapter 3 ( ) Orlando Fals Borda 2019. Authorized by CLACSO, the publisher; Comment $(\odot$ Juan Ignacio Piovani 2019

Chapter 4 @ Aníbal Quijano 2019; Comment @ Cláudio Costa Pinheiro 2019

Chapter 5 () Edelberto Torres Rivas 2019; Comment @ Sergio

Villena Fiengo 2019

Chapter 6 @ Elizabeth Jelin 2019; Comment @ Teresa Valdés Echenique 2019

Chapter 7 ( ) Raquel Sosa Elízaga 2019

Chapter 8 @ Sergio Bagú 2019. Authorized by his son, Claudio Bagu and Siglo XXI-México, the publisher; Comment @ Pablo de Marinis 2019

Chapter $9 \odot$ Alma Reyles, 2014. Authorized by Seagull Books; Comment (C) Oscar Vega Camacho 2019

Chapter 10 ( ) Arturo Escobar 2019; Comment @ Irene Piedrahíta Arcila 2019

Chapter 11 @ Bolívar Echeverría's heirs, Modernidad y blanquitud,

Ediciones Era, México, 2010; Comment @ Márgara Millán 2019

Chapter 12 @ Nadya Araujo Guimarães 2019

Chapter 13 @ J José Carlos Mariátegui 2019; Comment @ José-Carlos Mariátegui Ezeta 2019

Chapter $14 \odot$ Florestan Fernandes 2019. Authorized by the publisher CLACSO; Comment (C) Antonio Sérgio Guimarães 2019

Chapter 15 () Rodolfo Stavenhagen 2019. Authorized by Elia

Stavenhagen; Comment () Francisco Zapata Schaffield 2019

Chapter 16 @ José Nun 2019. Authorized by José Nun and Fondo de

Cultura Economica, the publisher; Comment ( ) Gabriel Kessler 2019

Chapter 17 () Marina Ariza and Orlandina de Oliveira 2019; Comment

(C) Brígida García 2019

Chapter 18 @ Breno Bringel 2019

Chapter 19 () Duke University Press, 2012. All rights reserved.

Republished by permission of the copyright holder, Duke University

Press; Comment (C) Maristella Svampa 2019

Chapter 20 ○ Eder Sader. Authorized by heirs and translator Gerónimo de Sierra 2019; Comment () Maria da Glória Gohn

Chapter 21 ○ Virginia Vargas. Authorized by CLACSO and Virginia Vargas 2019; Comment (C) Susana Rostignol 2019

Chapter 22 ( ) Enrique de la Garza Toledo 2019; Comment

(c) Patricia Collado 2019

Chapter 23 () Manuel Antonio Garretón 2019

Chapter 24 () Suzy Castor. Authorized by Éditions de la Maison des Sciences de l'Homme, the publisher; Comment (C) Patricia Funes 2019 Chapter 25 () Ernesto Laclau 2019. Authorized by Chantal Mouffe and Nueva Sociedad, the publisher; Comment (C) Paula Biglieri 2019

Chapter 26 @ Guillermo O’Donnell 2019. Authorized by Nueva Sociedad, the publisher; Comment $\odot$ Maria Hermínia Tavares de Almeida 2019

Chapter 27 ( ) Bernardo Sorj 2019; Comment @ Carlos Ruiz Encina 2019

First published 2019

Apart from any fair dealing for the purposes of research or private study, or criticism or review, as permitted under the Copyright, Designs and Patents Act, 1988, this publication may be reproduced, stored or transmitted in any form, or by any means, only with the prior permission in writing of the publishers, or in the case of reprographic reproduction, in accordance with the terms of licences issued by the Copyright Licensing Agency. Enquiries concerning reproduction outside those terms should be sent to the publishers.

Library of Congress Control Number: 2018964096

British Library Cataloguing in Publication data

A catalogue record for this book is available from the British Library

ISBN 978-1-5264-9026-1

ISBN 978-1-5264-9025-4 (pbk)

At SAGE we take sustainability seriously. Most of our products are printed in the UK using responsibly sourced papers and boards. When we print overseas we ensure sustainable papers are used as measured by the PREPS grading system. We undertake an annual audit to monitor our sustainability. 


\section{Contents}

About the Editor ix

About the Contributors $\quad \mathrm{x}$

Acknowledgments $\quad$ xxi

\section{INTRODUCTORY STUDY}

Latin American Sociology: A Centennial Regional

Tradition

Fernanda Beigel (Argentina)

PART ONE FOUNDING PROBLEMS

1 Founding Problems and Institutionalization of Sociology in Latin America

Jorge Rovira Mas (Costa Rica)

2 Alberto Guerreiro Ramos (Brazil)

A Critical Introduction to Brazilian Sociology:

Canned Sociology versus Dynamic Sociology

Comment by João Maia (Brazil)

3 Orlando Fals Borda (Colombia)

Theoretical-Practical Experiences: General

Working Guidelines on Participatory Action

Research (PAR)

Comment by Juan Ignacio Piovani (Argentina)

4 Aníbal Quijano (Peru)

Of Don Quixote and Windmills in Latin America

Comment by Cláudio Costa Pinheiro (Brazil) 
5 Edelberto Torres Rivas (Guatemala-Costa Rica)

On the Pessimism in the Social Sciences

Comment by Sergio Villena Fiengo (Costa Rica)

6 Elizabeth Jelin (Argentina)

The Foundations of a New Issue: Gender,

Human Rights and Memory

Comment by Teresa Valdés Echenique (Chile)

\section{PART TWO HISTORICAL AND}

7 Understanding Historical and Contemporary Debate in Latin American Sociology: Enlightening Paths

Raquel Sosa Elízaga (Mexico)

8 Sergio Bagú (Argentina-Mexico)

Building Theory

Comment by Pablo de Marinis (Argentina)

9 René Zavaleta Mercado (Bolivia)

The Struggle for Surplus

Comment by Oscar Vega Camacho (Bolivia)

10 Arturo Escobar (Colombia-US)

Development (Again) in Question: Trends in

Critical Debates on Capitalism, Development

and Modernity in Latin America

Comment by Irene Piedrahíta Arcila (Colombia)

11 Bolívar Echeverría (Ecuador-Mexico)

The 'American' Modernity (Keys to Its Understanding)

Comment by Márgara Millán (Mexico)

\section{PART THREE SOCIAL STRUCTURE}

AND INEQUALITIES

12 Inequality, Inequalities

Nadya Araujo Guimarães (Brazil) 
13 José Carlos Mariátegui (Peru)

The Problem of Race: Approaching the Issue

186

Comment by José-Carlos Mariátegui Ezeta (Peru)

14 Florestan Fernandes (Brazil)

The Weight of the Past

Comment by Antonio Sérgio Alfredo Guimarães (Brazil)

15 Rodolfo Stavenhagen (Mexico)

The Dynamics of Inter-ethnic Relations:

Classes, Colonialism and Acculturation

Comment by Francisco Zapata Schaffeld (Mexico)

16 José Nun (Argentina)

Marginality and Social Exclusion (Fragments)

Comment by Gabriel Kessler (Argentina)

17 Marina Ariza and Orlandina de Oliveira (Mexico)

Households, Families and Social Inequalities

in Latin America

Comment by Brígida García (Mexico)

\section{PART FOUR IDENTITIES, ACTORS AND}

SOCIAL MOVEMENTS

18 Latin American Perspectives on Social

Movements Research

Breno Bringel (Brazil)

19 Silvia Rivera Cusicanqui (Bolivia)

Ch'ixinakax utxiwa: A Reflection on the Practices

and Discourses of Decolonization

Comment by Maristella Svampa (Argentina)

20 Eder Sader (Brazil)

New Players Came on Stage - São Paulo Workers'

Experiences, Language, and Struggles (1970-1980)

Comment by Maria da Glória Gohn (Brazil) 
21 Virginia Vargas (Peru)

Latin American Feminisms and Their Transition

to the New Millennium (A Personal Political Reading)

Comment by Susana Rostagnol (Uruguay)

22 Enrique de la Garza Toledo (Mexico)

Trade Union Models in Latin America,

Before and After

Comment by Patricia Collado (Argentina)

PART FIVE STATE, SOCIETY AND POLITICS

23 Politics, State and Society in Latin American Sociology:

A Partial Introduction

Manuel Antonio Garretón (Chile)

24 Suzy Castor (Haiti)

The Secular Roots of a Difficult Nation-building

Comment by Patricia Funes (Argentina)

25 Ernesto Laclau (Argentina-UK)

The Populist Turn and the Center-Left in Latin America

Comment by Paula Biglieri (Argentina)

26 Guillermo O'Donnell (Argentina-US)

On Certain Aspects of the Crisis of the State

Comment by Maria Hermínia Tavares de Almeida (Brazil)

27 Bernardo Sorj (Uruguay-Brazil)

Political Activism in the Era of the Internet

Comment by Carlos Ruiz Encina (Chile) 


\section{About the Editor}

Fernanda Beigel is a sociologist and holds a degree in Social and Political Sciences. Principal Researcher at CONICET (INCIHUSA, Mendoza, Argentina), Head Professor in Latin American Sociology and Director of the Doctoral Program at the National University of Cuyo. She is the director of the Research Program on Academic Dependency in Latin America (PIDAAL) since 2004. Her doctoral studies were fulfilled under the guidance of Arturo Andrés Roig and her postdoctoral studies at the Centre de Sociologie Européenne (EHESS, Paris) with Gisèle Sapiro. Awards include: Bernardo Houssay Award (2003), CLASCO International Essay First Prize (2004) and Mention of Honor for Scientific Value (2017). A specialist in the Sociology of Science and Latin American Sociology, her most recent publications are: The Politics of Academic Autonomy in Latin America (Ashgate); 'Publishing From the Periphery: Structural Heterogeneity and Segmented Circuits: The Evaluation of Scientific Publications for Tenure in Argentina's CONICET' (2014) Current Sociology, 62(5), pp. 743-765; (2016) 'El nuevo carácter de la dependencia intelectual' (2016) Cuestiones de Sociologia, 14, pp. 45-68; 'Peripheral Scientists, between Ariel and Caliban. Institutional Know-how and Circuits of Recognition in Argentina. The Career-best Publications of the Researchers at CONICET' (2017) Dados-Revista de Ciências Sociais, Rio de Janeiro, 60(3), pp. 825-865; with O. Gallardo and F. Bekerman, 'Institutional Expansion and Scientific Development in the Periphery: The Structural Heterogeneity of Argentina's Academic Field' (2018) Minerva, 56(3), pp. 305-331; 'Las relaciones de poder en la ciencia mundial. Un anti-ranking para conocer la ciencia producida en la periferia' (2018) Nueva Sociedad, 74, pp. 13-28. 


\section{About the Contributors}

Note: biographies of the authors of the key texts are provided in Comments by specialists.

Paula Biglieri holds a Doctoral degree in Political and Social Science from the National Autonomous University of Mexico (UNAM). She is a researcher at the National Scientific and Technical Research Council (CONICET) in Argentina and she is also the Head of the Cátedra Libre Ernesto Laclau of the School of Philosophy and Letters at the University of Buenos Aires. She co-directs the research project 'Theorising Transnational Populist Politics' funded by the British Academy and hosted by the Cátedra Libre Ernesto Laclau and the Centre for Applied Philosophy, Politics and Ethics, University of Brighton. Annually, she leads the graduate seminar on 'Psychoanalysis, Rhetoric and Politics' at the Cátedra Libre Ernesto Laclau. Her theoretical research is mainly focused on the relation between psychoanalysis and politics, particularly considering the theoretical dimension of populism. She has also studied the cases of the so-called 'last Latin American populist tide'. She has published numerous papers and essays in Argentina, Brazil, Ecuador, Mexico, Slovenia, the UK and the US. She has also co-authored the books, In the Name of the People. The Emergence of the Kirchnerista Populism [En el nombre del pueblo. La emergencia del populismo kirchnerista] (UNSAM Edita, 2007); and The Uses of Psychoanalysis in Ernesto Laclau's Theory of Hegemony [Los usos del psicoanálisis en la teoría de la hegemonía de Ernesto Laclau] (Grama Ediciones, 2012).

Breno Bringel holds a Doctoral degree from the Faculty of Political Science and Sociology (Universidad Complutense de Madrid). He has been a Visiting Professor at universities in Argentina, Brazil, Chile, Uruguay, Portugal, Spain, France, Switzerland and the United Kingdom. $\mathrm{He}$ is currently a Professor of Sociology at the Institute of Social and Political Studies at the State University of Rio de Janeiro (IESP-UERJ) 
where he coordinates the Doctoral Program in Sociology and leads, with José Mauricio Domingues, the Research Group on Social Theory and Latin America. He is the President of the Research Committee on Social Classes and Social Movements (RC-47) at the International Sociological Asssociation (ISA) and Editor of Open Movements, a partnership between Open Democracy and ISA RC-47. His main areas of research are political sociology and Latin American sociology and his most recent book is Critical Geopolitics and Regional (Re)Configurations: Interregionalism and Transnationalism Between Latin American and Europe (Routledge, 2019). In this same ISA Series (Sage Studies in International Sociology) he edited the book Global Modernity and Social Contestation (Sage, 2015).

Oscar Vega Camacho is an independent Bolivian writer and researcher on philosophy, literature and the arts. He has collaborated in academic journals and magazines, and published Errancias. Aperturas de vivir bien in 2011. He was a counselor of the Cultural Foundation of the Central Bank of Bolivia (2011-2016), and Visiting Researcher at the Center for Constitutional Studies of the Bolivian Catholic University 'San Pablo' (2010-2013). He was part of the Presidential Representation for the Constituent Assembly (2007-2008) and is a member of the group Comuna.

Patricia Collado is a Sociologist and Doctor in Political and Social Sciences; She has a Master's in Social Sciences (FLACSO; Diploma in Political Economy-FLACSO). She is a researcher at CONICET (INCIHUSA, Mendoza, Argentina). She is Director of the Master's Program in LatinAmerican Studies (UNCuyo) and Head Professor at the UNCuyo. Her current research projects include: 'Class and political subjectivation. Return to clasic discussion from the changes of contemporary labour'. Her research field is contemporary work studies, trade unionism, social conflicts and social movements. Recent publications include: Citizenship, Mobilization and Social Conflict in collaboration with Bonifacio J. L. and Vommaro G. (PISAC, 2017); In collaboration with Montes Cató J. "Recurrent themes, emergent topics, neccesary dialogues in labour studies" (Revista del CIEP - 2016); "How is class? A reflection about antagonism labour conflict" (Herramienta 2015), Conflicts Around Labour. A Comparative Analysis of Mendoza, Córdoba and Buenos Aires (UNGS, 2015).

Maria Hermínia Tavares de Almeida is a Political Scientist and $\mathrm{PhD}$ (Universidade de São Paulo and University of California, Berkeley) Senior 
Researcher at Centro Brasileiro de Análise e Planejamento (CEBRAP), Professor at the University of São Paulo (retired) and Professor at the Graduate Programs of International Relations and Political Science. She has published the books Economic Crisis and Organized Interests (Edusp, 1993) and, with Gian Luca Gardini, Foreign Policy Responses to the Rise of Brazil - Balancing Power in Emerging States (Palgrave Macmillan, 2016) and The Golgen Age - Essays on Democracy in Brazil (Horizontes, 2019). She holds the Brazilian National Order of Scientific Merit (2006).

Pablo de Marinis is a Sociologist(Universidad de Buenos Aires, Argentina, 1991) and holds a DPhil in Philosophy (Universität Hamburg, Germany, 1997). He teaches sociological theory in the Sociology Department of the Facultad de Ciencias Sociales, Universidad de Buenos Aires. He conducts research at the Instituto de Investigaciones Gino Germani, at UBA/ CONICET. His main research topics are related to the concepts of 'community' and 'mass/crowd' through the history of sociological theory. He is also concerned with methodological questions of theoretical sociological research and his main publications deal with these issues: www.uba. academia.edu/PablodeMarinis.

Teresa Valdés Echenique is a Sociologist (PUC Chile). Between 1981 and 2006 she was a researcher at FLACSO-Chile, where she was a Professor and created the Gender Studies Area, where she conducted a great deal of research. She coordinated the regional projects 'Latin American Women in Figures' and the 'Index of Fulfilled Commitment' (IFC), a strategy for the citizen control of gender equity. She was a researcher at the Center for Studies for the Development of Women (CEDEM) (2006-2012), Visiting Professor at Stanford University (1996-2007) and Professor at various Chilean universities. She was Gender Advisor to the Minister of Health and Head of the Gender Unit of the Ministry of Health (2014-2018). She has published and edited numerous books and articles on gender issues, social participation and citizen control. She received the 'Elena Caffarena' award in 2003 in the category of Women Researcher in Science and Education, awarded by SERNAM-Santiago. Since 2007 she has coordinated the Observatory of Gender and Equity.

João Maia is Associate Professor at CPDOC/School of Social Sciences, Fundação Getulio Vargas (Rio de Janeiro, Brazil). He holds a Doctoral 
degree in Sociology from IUPERJ and a Masters degree from the same institution. His research interests span the history of sociology, social theory and the sociology of science and intellectuals. He co-authored the book Knowledge and Global Power: Making New Sciences in the South (Monash, 2018) and 'Negotiating with the North: How Southern tier intellectuals workers deal with the global economy of knowledge' (2017) The Sociological Review, 66 (1), pp. 41-57. He also authored 'History of Sociology and the quest for intellectual autonomy in the Global South: the cases of Alberto Guerreiro Ramos and Syed Hussein Alatas', Current Sociology, 62(7), pp. 1097-1115, 2014).

Irene Piedrahita Arcila is an Anthropologist, Magister in Political Science and Research Professor at the Institute of Political Studies of the University of Antioquia, Medellin, Colombia. She is currently the coordinator of the research group Hegemony, Wars and Conflict. Her work focuses on political anthropology and the State, particularly in ethnographic works, in which she has conducted research on the Colombian peasantry and the connection between memories associated with the armed conflict and the construction of the State. She has published numerous articles and working texts on memory, statehood and peasant communities in protected areas. Her recent book include: ¿Un Estado Vigilante, Negociador, Ambiguo? Formas en que opera el Estado en el Orquídeas National Natural Park (2018).

Raquel Sosa Elízaga is Doctor in History and Professor at the Center for Latin American Studies (CELA) at the National Autonomous University of Mexico. With a vast academic trajectory, she participates actively in the public debates of the Mexican and Latin American society. Among her recent publications are: "Pensar con cabeza propia. Educación y pensamiento crítico en América Latina" (Cuadernos del Pensamiento Critico, 2011); Temas y Procesos de la Historia Reciente de América Latina (CLACSO 2010); Encrucijadas Abiertas. América Latina y el Caribe. Sociedad y Pensamiento Crítico Abya Yala (CLACSO, 2018); Hacia la Recuperación de la Soberanía Educativa en América Latina, CLACSO/UNAM, 2010 and Educación y Exclusión, Facultad de Ciencias Políticas y Sociales de la UNAM, 2016. She currently conducts a large public university programme in Mexico, Universidades para el Bienestar Benito Juárez García, and is general director of CREFAL, 
Centro Regional para la Educación Fundamental en América Latina y el Caribe.

Carlos Ruiz Encina is a Sociologist and Doctor in Latin American Studies and a Professor at the Sociology Department and the Doctoral Program in Social Sciences and Latin American Studies (Universidad de Chile). He was Director of the Sociology Department (2014-2018). He is President of Nodo XXI Foundation, an intellectual institute related with the Chilean Frente Amplio. His research areas are state, development studies, conflict and social structure. He participates actively in public debates linked to democracy and development in Chile and Latin America.

José-Carlos Mariátegui Ezeta is a scientist, writer and curator working on culture, new media and technology. He studied Biology and Applied Mathematics at Cayetano Heredia University (Lima) and holds both a Master's and Doctoral degrees in Information Systems and Innovation from the London School of Economics and Political Science (LSE). He conceived and curated international original exhibitions and events in new media art and on the history of science and technology. He has published in journals such as Third Text, The Information Society, Telos and Leonardo. He is founding Director of the José Carlos Mariátegui Memorial Museum (1995-2005) and currently Director of the José Carlos Mariátegui Archive (www.mariategui.org) in Lima. He is currently Editorial Board member for Leonardo Books at MIT Press, Advisory Board member for AI \& Society (UK) and of the Bicentenary of the Independence of Peru Committee.

Sergio Villena Fiengo holds a doctorate in Studies of Society and Culture, is Professor at the School of Sociology and Director of the Institute of Social Research (IIS) at the University of Costa Rica (UCR). He is a specialist in Latin American sociology and the sociology of culture and arts. His profile and publications can be found at https://ucr.academia.edu/ SergioVillenaFiengo.

Patricia Funes, $\mathrm{PhD}$, has been Professor of Latin American History at the Social Sciences Faculty, University of Buenos Aires (UBA) since 1999, and, since 2005, Senior Researcher, Consejo Nacional de Investigaciones Científicas y Técnicas (National Scientific and Technical Research Council) at the Gino Germani Research Institute, Social Science Faculty, University of Buenos Aires. Her research topics are related to the history of ideas, political history and memory in Latin American in the 
twentieth century. Her current research project is 'Sources, Shapes and Representations of the Recent Past. Personal Archives: History, Memory and Biography'. Her recent books include: Historia mínima de las ideas políticas en América Latina (El Colegio de México/Turner, México/ Madrid, 2014) and Revolución, dictadura y democracia. Lógicas militantes y militares en la historia reciente de Argentina en América Latina (Imago Mundi, Buenos Aires, 2016).

Brígida García is Professor-Researcher at the Centro de Estudios Demográficos, Urbanos y Ambientales (CEDUA), El Colegio de México, Mexico City. She holds a Master's degree in Demography from this same institution and a Doctoral degree in Sociology from the National Autonomous University of Mexico (UNAM). Her research areas include family, work and gender in Mexico and Latin America. She has held the post of President of the Mexican Demographic Society (Somede). In 2015 she was named Emeritus Researcher by the National System of Researchers in Mexico (SNI). Her recent publications cover the topics of households and workers, time use and non-paid work.

Manuel Antonio Garretón, is a Sociologist (Universidad Católica, Chile) and has a PhD from the École des Hautes Études en Sciences Sociales (Paris). He has been the director of several academic institutions and a professor at various national and international universities. His areas of research and teaching are political sociology, transition to democracy, State and society, authoritarian regimes, actor and social movements, political parties, education and the university, public opinion and social demands, education and culture, development of the social sciences, sociological theory and modernity and society in Latin America. He participates actively in political and cultural debates in Chile and Latin America in the intellectual and mass media context. Since 1994 he has been Professor at the Department of Sociology at the Faculty of Social Sciences, Universidad de Chile. He was awarded the Chilean National Prize in Social Sciences (2007) and the Kalman Silvert Award (2015) by the Latin American Studies Association (LASA).

Maria da Glória Gohn is a Sociologist and holds a Doctoral degree in Political Science from the University of São Paulo, Brazil (1983); Post$\mathrm{PhD}$ in the New School of University, New York (1996-97). She is Professor at University of Campinas (UNICAMP) and Visiting Professor at Federal University of $\mathrm{ABC}$ (UFABC). She is Researcher $1 \mathrm{~A}$ of the 
National Council of Research (CNPq) and former Vice-President of the Research Committee 47 of the International Sociological Association (ISA). Her research and teaching fields are: social movements, social theories, urban participatory counsels and social mobilization by NGOs. She has published twenty books on social movements and social participation of the civil society such as: Manifestações e Protestos no Brasil: Correntes e contra correntes na atualidade (Cortez, 2017); Manifestações de Junho de 2013 no Brasil e Praças dos Indignados no Mundo (Vozes, 2014); Movimentos Sociais e Redes de Mobilizações no Brasil Contemporâneo (Vozes, 2014), Teoria dos Movimentos Sociais (Loyola, 2014), Novas Teorias dos Movimentos Sociais (Loyola, 2014) and O Protagonismo da Sociedade Civil (Cortez, 2008).

Antonio Sérgio Alfredo Guimarães holds a $\mathrm{PhD}$ in Sociology from the University of Wisconsin-Madison (1988). He is a Researcher at CEBRAP-São Paulo, and Senior Professor of Sociology at the University of São Paulo. He held the Simon Bolívar Chair of Latin American Studies at the University of Cambridge (2016-2017), the Chaire brésilienne de sciences sociales Sérgio Buarque de Holanda, Fondation Maison des sciences de l'Homme (2010-2014), the Lemman Distinguished Chair at the University of Illinois at Urbana-Champaign, and was a Visiting Professor at Princeton University and the Federal University of Bahia, among others. His research field is racial, national and class identities; Black social movements; affirmative action and Black intellectuals. He has published several books, including: Preconceito Racial - Modos, Temas, Tempos (Cortez, 2008); Classes, raças e democracia (Editora 34, 2002); Racismo e anti-racismo no Brasil (Editora 34, 1999; 2e. Edição 2005).

Nadya Araujo Guimarães holds the Chair in the Sociology of Work, Department of Sociology at the University of São Paulo. She is also a Senior Researcher associated with CEBRAP (Brazilian Center for Analysis and Planning), and in 2016 was inducted into the Brazilian Academy of Sciences. Nadya Guimarães received her Doctoral degree from the Universidad Nacional Autónoma de México (1983) and carried out post-doctoral studies at the Massachusetts Institute of Technology (MIT) Special Program on Urban and Regional Studies for Developing Areas (1993-1994). She has undertaken research in the following areas: the Brazilian labour market, focusing on economic change and workers' trajectories; comparative studies on unemployment, employment flexibility and labour market intermediaries; gender/race inequalities; and 
care and care workers. She recently co-authored Etre chômeur à Paris, São Paulo et Tokyo (Presses de Sciences Po, 2013) and the chapter 'The Future of Work', in Rethinking Society for the 21st Century (Cambridge University Press, 2018). She also co-edited Genre, Race, Classe. Travailler en France et au Brésil (L'Harmattan, 2016).

Gabriel Kessler is a Sociologist and holds a $\mathrm{PhD}$ in Sociology from the École des Hautes Études en Sciences Sociales (Paris). He is Principal Researcher at the National Council of Scientific and Technical Research (CONICET), Professor of Sociology at the Universidad Nacional de La Plata (UNLP) and at the Universidad Nacional de San Martín, Argentina. His research focuses on inequality, violence and Latin America social structure. Recent books include: Controversias sobre la desigualdad (Fondo de Cultura Económica, 2015), La sociedad Argentina hoy (Siglo XXI, 2016) and Muertes que importan (with S. Gayol, Siglo XXI, 2018).

Jorge Rovira Mas is a Sociologist and holds a Doctoral degree in Sociology From Universidad Nacional Autónoma de México (1980). He was Professor and Researcher at the Universidad de Costa Rica (1970-2013) in the School of Sociology and the Social Research Institute and has been Emeritus Professor since 2016. The author and editor of several books, he has also published numerous articles in specialized journals and contributed with chapters of books in national and international editions. Awards include: Jorge Volio, Cleto González Víquez in National History and Humboldt (2009) from the Deutscher Akademischer Austausch Dienst (DAAD).

Márgara Millán is a Sociologist and Social Anthropologist, Professor at the Faculty of Political and Social Sciences, National Autonomous University of Mexico and researcher at the Center for Latin American Studies (CELA, UNAM). Her research areas include: social movements, cultural representations in gender, and the critique of modernity. She was Coordinator of the collection 'Teoría Social Latinoamericana' (1994-1996), along with Ruy Mauro Marini, and Director of the research projects 'Alternative Modernities and New Common Sense' (2011-2014) and 'Political Prefigurations' (2015-2016). Her main articles include: 'Derivas de un cine en femenino' (1999), 'De-centering gender, Re-ordering nation; Zapatism of Indigenous women and its consequences' (2014), and her most recent books are Modernidades alternativas (2017) and Prefiguraciones de lo politico (2018). She is also a founder of 
Con Nosotros, a civil association that promotes the inclusion of people with disabilities.

Cláudio Costa Pinheiro is currently Professor of Asian and African Studies at Rio de Janeiro Federal University, Brazil; Chairman of Sephis Programme, Netherlands; International Scholar, Universität zu Köln, Germany; Visiting Professor for Critical Studies in Higher Education Transformation, Nelson Mandela University, South Africa. His research interests include two main axes: knowledge production and circulation, and structures of power, slavery and forms of dependency, both of which consider the impact and durable effects of colonialism in the institutionalization of power in Western and non-Western societies. He is or has been Visiting Professor or Fellow at the Universities of: (in the US) Wellesley College/Harvard University; (in Europe) Universities of Vienna, Cologne, Humboldt and Free University of Berlin and University of Lisbon; (in India) the University of Calcutta, of Goa, of Delhi, at the Center for the Study of Developing Societies, and at Bukkyo University (Kyoto, Japan). Recent publications include with Schröder, P. and Vermeulen, H. (editors) (2019) 'The German Tradition in Latin-American Anthropology', special issue. Revista de Antropologia Journal, 62 (1) 2019; 2018c. Unhomely Afterlives, with Williams and Hentschke (eds). To Be at Home. Berlin: De Gruyter, 210218, 2017. Modernity and the artifices of Place-making. AEGS - Annual of European and Global Studies, 4, June/July 2017, 51-71.

Juan Igancio Piovani is a Sociologist with an MSc in Advanced Social Research Methods and Statistics (City, University of London, UK) and a $\mathrm{PhD}$ in the Methodology of the Social and Political Sciences (Sapienza University of Rome, Italy). He is a full Professor of Social Research Methods (Department of Sociology, Faculty of Humanities, National University of La Plata, Argentina) and Principal Researcher of the National Scientific and Technical Research Council (CONICET) at the Institute of Humanities and Social Sciences (IdIHCS). Among his most recent books are Manual de metodología de las ciencias sociales (with A. Marradi and N. Archenti, Siglo XXI, 2018); La Argentina en el siglo XXI. Cómo somos, vivimos y convivimos en una sociedad desigual (co-edited with A. Salvia, Siglo XXI, 2018) and ¿Condenados a la reflexividad? Apuntes para repensar el proceso de investigación social (co-edited with L. Muñiz Terra, Biblos-CLASCO, 2018). 
Susana Rostagnol holds a Doctoral degree in Social Anthropology and is Director of the Department of Social Anthropology (Universidad de la República, Uruguay), and is part of the National Researchers System and coordinator of the Gender, Body and Sexuality Program. Her Research areas include: gender, body and sexuality; gender-based violence, feminist theory and methodology. She has carried out fieldwork in Uruguay and in Andalucía (Spain). Currently she is researching the neoconservative movement and sexual and reproductive rights. She has published several articles and books, the latest include 'Abortion in Andalusia: women's rights and the Gallardón Bill' (Antropologia, vol 5, No. 2, 2018), 'La relación etnográfica en el campo y en el escritorio' (Disparidades, vol 74, No. 1, 2019) and 'Los meandros políticos de la ciudadanía sexual y los derechos sexuales y reproductivos' (Siglo XXI, Mexico, 2019).

Francisco Zapata Schaffeld holds a PhD in Sociology from the University of Paris (1970) and has been a Professor at El Colegio de México since 1974, where he was Chair of the Department of Sociological Studies from 1994 to 2000. He has been a member of the National System of Research since 1984. He teaches courses in the Doctorate Program in Social Science on classical sociology, the sociology of work and the history of the Latin American labour movement. His research areas include: analysis of the class consciousness of striking miners in Bolivia, Chile, Mexico and Peru and the history of Latin American labour. He was Professor at the Yale University Latin American Program (2000) and Fellow at the Kellog Institute of the University of Notre Dame (2002). He has collaborated on various graduate programs at the University of Santiago, Chile (USACH) and the Catholic University of Northern Chile. His most recent publications are: Ideología y política en América Latina (El Colegio de México, 2nd edition 2016); Historia minima del sindicalismo latinoamericano (El Colegio de México, 2013); and 'Ciencias sociales y desarrollo nacional en México’, Antropologías del Sur, no. 2, 15-29 (2014).

Bernardo Sorj received his $\mathrm{PhD}$ in Sociology from the University of Manchester in England. He is the Director of the Edelstein Center for Social Research and Plataforma Democrática, a joint project with the Fernando Henrique Cardoso Foundation. He was Professor of Sociology at the University of Rio de Janeiro, visiting professor and chair at many European, North American and Latin American universities. The author 
of 30 books and more than 100 academic articles on social theory, international relations, the social impact of new technologies and Latin America political development, he is member of the board of several academic journals, and consultant to governments and international organizations.

Maristella Svampa is a Sociologist, writer and researcher. She has a degree in Philosophy from the National University of Córdoba and a PhD in Sociology from the École des Hautes Études en Sciences Sociales., France. She is Principal Researcher at CONICET and Professor in Latin American Social Theory at the National University of La Plata (Argentina). In 2006 she obtained the Guggenheim Scholarship and in 2016 the Kónex Platinum Award in Sociology (Argentina). Among her latest books are: Latin American Debates. Indianism, Development, Dependency and Populism (2016); From the Change of Time to the End of the Cycle. Progressive Governments, Extractivism and Social Movements in Latin America (2017). Development in Latin America: Toward a New Future Canada and Neo-extractuinism Dynamics in Latin America: Socio-environmental Conflicts, The Territorial Turn and New Political Narratives (Cambridge University Press). She is also the author of three novels, Los reinos perdidos (2006), Where Our Dead are Buried (2012) and The Wall (2013). 


\section{Acknowledgments}

This volume was conceived in the periphery of the periphery: the city of Mendoza (Argentina), in a workshop held in 2012, where the scientific committee discussed the difference between 'classics' and 'key texts'. It is the result of five years of collaboration between many colleagues of 15 Latin American countries that committed to the project and helped with different tasks: the formulation of the project, the translations, queries in archives to confront translation issues, author rights and contacts with heirs or publishing houses. More than half of the volume was slowly translated into English thanks to this collective commitment. The rest of the volume remained untranslated and kept the book waiting for a long time until the International Sociological Association generously funded the rest of the translations. We thank the ISA for their support in broadening the circulation of the knowledge produced in this region. The credit for the collaborations that produced the individual translations are noted where appropriate. The rest (Chapters 8, 10, 11, 18, 20, 21, 23, 24, 25 and 26) were translated by Mariana Donadini, whom we thank for her professionalism. 


\title{
Introductory Study
}

\section{Latin American Sociology: A Centennial Regional Tradition}

\author{
Fernanda Beigel (Argentina)
}

The mere mention of French, US or German Sociology refers readers to world renowned disciplinary traditions whose legitimate foundations are beyond doubt. The so-called founding fathers of 'international' Sociology (Marx, Weber and Durkheim) and other sociologists from these national fields are conceived as the sources of original and 'universal' theories and methods. However, it is fair to recognize that their circulation and legitimacy are not detached from the material and symbolic power of those nation-states during the period of institutionalization/internationalization of Sociology. In this context, these sociological powers were 'blessed' by the diffusion of their particular originality and gifted with an international universality. Conversely, the 'universality' and 'originality' of Latin American Sociology has been under scrutiny - either because its production was mainly published in Spanish/Portuguese, thus had scarce circulation outside the region, or because its commitment to social change led to the prejudice that it produced only ideological essays. Sometimes even its own practitioners have felt that they are a retort of concepts and methods elaborated at the 'centers of excellence'. However, Sociology in Latin America has its own local, national and regional traditions.

Unlike the dominating national form of development, the institutionalization of Sociology in Latin America was regional (thus, international) from its birth. In fact, the national sociologies evolved in parallel with the appearance of the Latin American Sociology Association (ALAS) in 1950 and other institutions that gave the impulse to a regional research space. The founders of the first Sociology schools took advantage of the material and symbolic stimulus given to the social sciences during the second post-war period. Several regional centers for teaching and research were created and most of them were installed in Santiago de Chile which became the main axis of a regional academic circuit. From this platform, Latin American Sociology emerged as a regional tradition with its own 
path, differentiated from national sociologies, developed through reflection on the continent's main common historical and social problems: colonization, development, dependency, poverty. All this was possible because of the existence of a regional intellectual space with a long and rich history, as we will see next.

Very frequently the center-periphery focus has been introduced to the study of science, assuming that peripheral communities are dependent and marginal while central communities are autonomous and international. In other studies (Beigel, 2013) I have criticized the concept of academic dependency when it is attached to an image of a passive periphery reduced to the role of importer of foreign knowledge, subordinate to an active center considered as the main exporter and producer of 'original' knowledge. Intellectual production is not a simple equation based on economic or political national development, although international circulation is indeed more dependent on material structures and traditional hierarchies. In fact, theories and methods produced outside the mainstream centers have been rarely 'exported' into mainstream circuits, but this is not to imply these are the result of massive imports of central models. Rather the contrary, I argue here that this regional tradition still influences the practice and theory of many sociologists today.

The history of Sociology in Latin America and its different national traditions can be traced back to 1882 when the first chair was created at a university in a capital city. However, Latin American Sociology (LAS), as a specific research field is a centennial tradition born by the mid-1920s and consolidated by the 1960s with the emergence of its own focus and regional institutions. As will be proven by the wide range of key texts contained in this volume, most of them have never been translated into English before, and accordingly they did not circulate in the North, but formed sociologists throughout the whole region, crossing different countries and sociology schools.

In the first part of this chapter I will address a socio-historical account of the development of this regional focus and a field approach to understanding its specific process of institutionalization, as well as the role played by politicization, along with the features of the regional circuit and its external pressures. Secondly, I will analyze the nature of the traditions involved in the construction of its perspective and the weight of the historicalstructural method. Thirdly, I will delve into the particular relevance of a conceptual trilogy (nation, class and race) that has been reinterpreted 
at different historical stages. Finally, I will say a few words on 'critical' sociology and describe the general aims of this editing project and the organization of the volume.

\section{What is Latin American About Sociology in Latin America?}

In his recent book on French Sociology, Heilbron (2015) asks what is French about Sociology in France? He delves into the historical deconstruction of one of the most consolidated and unquestionably 'national' fields and observes the role played by the state structures and national contexts in the institutionalization of Sociology. He recognizes the role played by transnational exchange and international circulation but argues that these were built based on existing national structures. Besides, even if in recent times a de-nationalization of research practices occurred, also national loyalties and specificities were reinforced. He points out that the concept of 'national tradition' is in itself a problematic issue because it can be interpreted as a national style or as a mode of thinking attached to the 'character' or 'spirit' of a nation - something impossible to examine empirically or understand sociologically. It can refer to a practice or a way of working that spread beyond the founder of a school and its followers, acquiring national significance. It can relate to the structure of a given national academic field that comes into play also in producing certain conceptions of social science, in the reception of foreign authors and the selective ways these are incorporated in national debates. Rather than assuming the existence of immutable national minds, Heilbron argues it is more fruitful to identify the social processes that have unified intellectual habits or ways of thinking at a national level, particularly values and practices that have been institutionalized, whereas schools play a central role (2015: 220-222).

Indeed, Sociology has developed on the basis of national structures also in a peripheral region such as Latin America, where public universities have been a determinant for the emergence of 'national traditions'. However, the current debates on the internationalization of the social sciences leave aside the incidence of regional intellectual traditions and institutions that long ago called into question the 'national' and pre-existed the 'global'. This research void has to do with a common sense built on the basis of the national path crossed persistently by traditional United States (US) and European academic fields. But it can also be nourished by the experience of European economic integration and its failure to build a regional 
intellectual space. A comparison with the Latin American experience will be useful at this point.

Sapiro (2017) analyzes the process of formation of the nation-states, focusing on the disintegration of the lettered European community that befell with the abandonment of Latin and the affirmation of vernacular languages. The nationalization of the lettered culture gave an impulse to a process of differentiation of intellectual professions, and these were shaped according with the administrative structures of each country. In a space that was becoming increasingly dominant worldwide during the nineteenth century, the national identity and intellectual field-building process was highly competitive and endogamous. In the midst of the rivalry between the three great powers, France, Germany and the UK, after World War I came the first attempts to create a space for encounters between intellectuals committed to pacification. By 1924 the Institute for Intellectual Cooperation was created with the aim of encouraging internationalization beyond Europe - aside from the fact that the concept of Europe was subject to criticism given the ascent of Nazism. An initial sketch for economic regionalization started with the Marshall Plan in 1949, but the cultural integration was postponed for a long time because of political conflicts coming from bipolarity with communism, rivalries among nations and linguistic barriers. Sapiro argues that Europe was never consolidated as an intellectual space and integration is mainly sustained by experts and officers, not intellectuals. Besides, 'European identity' is not inculcated in school, and this regional space was built within the cultural hegemony of the US (Sapiro, 2017).

If we hold the Latin American space up to a mirror, an inverse image arises. Its regional experience and intellectual exchange is as old as Independence, two centuries already. Costa has argued that this region is not a homogeneous referential unit, but indeed a strongly compelling one (Costa, 2018). With similar colonial structures, the independence revolutions were part of an insurrection that extended beyond national frontiers. The leaders of this military feat were also in charge of the first intellectual reflections on indigenous government, an effort that delved in the opposition between the Spanish rule and the (South) 'American' independent nations, all seen as singular but twinned by history. A continental identity shared by the 'Hispanic-American' new nations was built through different meetings, battles and Congresses, and standing out, Simón Bolivar's Letter of Jamaica in 1815, where one of the main axes of Latinamericanity was founded: the idea of Hispanic America as 
a natural union against a common colonial enemy. As argued by Narvaja de Arnoux (2008), the style of these military-intellectuals was to illustrate battle through a project based on a historical narrative. Politics was conceived as a war and reason/good was believed to be on their side. The colonial rule was a threat for all the continent. The struggle for freedom and the defense against the Spaniards was a collective and sacrificial task.

This Independency narrative is still taught in primary education in most countries, and the schools' patriotic events recreate Bolívar and San Martín's continental battles for colonial liberation. Another traditional celebration, formerly called the 'Day of Race', honoring the date of the colonial discovery of America (October 12, 1492), was also experienced at primary schools. It became part of a regional discussion in 1992, under the 500th anniversary, and currently in most countries it has shifted to the 'Day of cultural diversity' or other such designation. But it is still performed in scholarly events to acknowledge the sacrifice of the original indigenous communities from the whole continent.

Accordingly, Latin-Americanism as a cultural, political and intellectual movement is rooted in Independence battles but it has several different phases and designations, starting with the Second Emancipation movement up to the Second Independence intellectuals who were worried by the limits of political independence by the end of the nineteenth century. Economic inequality and intellectual dependency were two main streams of debate when the first organic regional intellectual movement emerged: Hispanic-American Modernism. The crossroads between literature and the press was the platform for the development of this reflection, characterized by its opposition to the hegemonic aspirations of the US in conducting a Pan-American alliance and its pledge for a continental identity (Beigel, 1998).

It was only after the second post-war period when Latin-Americanism as such was born. Two main differences with Hispanic-American Modernism can be pointed out. The first was the entry of Brazil, formerly alien to the previous processes but playing a central role from the midtwentieth century until today. The second was the ideological shift that occurred with the displacement of Hispanism as the core of the tradition evoked against Pan-Americanism. A modern regional identity was built, along with the emergence of the Latin American Economic Commission (ECLA) created in 1948. It was in this context that the first attempt to create a common market appeared, the Latin American Association of 
Free Trade (ALALC, in its Spanish acronym) in 1961. A new regional philosophy was born, the social sciences received a great impetus and the literary 'boom' emerged. In the next years, this intellectual space became increasingly radicalized, attached to a local path to socialism created by the Cuban Revolution (1959), the guerrilla movements in the 1960s, Allende's democratic socialism (1970), Liberation Theology and the Nicaraguan Revolution (1979). The cultural movements remained and evolved, but the common market never achieved material results.

The questioning of Latin-America as a regional identity was to come during the 1990s from two opposite sides: (a) the neoliberal governments and the new wave of 'open regionalism'; and (b) postcolonial/decolonial studies developed by academic groups affiliated to US universities. The first had its milestone in the North American Free Trade Agreement (NAFTA), signed by Mexico, Canada and the US, and which came into force in 1994, an event that definitively changed the regional landscape. The second evolved in two different theoretical streams, one reinforcing postcolonial perspectives, and the other based on local traditions and developing the concept of coloniality of power.

In spite of this fall from grace, Latin-Americanism was resurrected recently during the leftist turn taken by the governments of Chavez, Kirchner, Lula, Morales and Mujica, as well as the creation of the Union of South American Nations (UNASUR) in 2008. The intellectual space was reinforced and several intra-regional agreements gave an impetus to a number of dynamical cultural, educational and scientific initiatives. Although again, economic integration did not survive the projection stage. A new cyclical phase arrived and is currently in progress after the governmental changes in many countries that seem to have seen the leftist turn move towards a right-wing shift. However, Latin-Americanism as an intellectual platform appears to be vivid and enduring even where commercial or political alliances have been weakened.

At this point, the initial question remains valid: what is Latin American about Sociology in Latin America? I am not referring to its development as a discipline within each national field, but as a specific focus and practice developed in a regional (and, by nature, international) research space. The 'Latin-Americanization' of Sociology emerges from the general cultural and political context described above but it has its own trajectory, sustained by specific regional institutions and singular state structures, such as the Chilean government that hosted the process. In previous studies (Beigel, 2010) I have explained how the structure of our regional academic circuit was 
built and the role played by its particular 'cosmopolis' based in Santiago (Beigel, 2010). The regional research centers such as ECLA (1948), FLACSO (1957), CELADE (1957), DESAL (1960), ILPES (1962) and ILADES (1965) contributed to the consolidation of this research field fueled mainly by the encounter of History, Sociology, Economics and Political Science.

Seeking for regional analogies and structural effects of the colonial heritage, development was addressed as a continental problem by the two regional academic traditions that emerged from this institutionalization process: ECLA Structuralism and Dependency Analysis. Radicalization stimulated the emergence of the latter more as a sociological paradigm than the former, closely linked to economics. The studies by the historians of Colonial Studies on the development of capitalism and the contributions made by the economists from ECLA were critical in the development of the Historical-Structural method that evolved in parallel - but with no contemporary contact - with the school of Annales and the French total History (Beigel, 2006b, 2013). Political dimensions became increasingly stressed by Dependentists as Marxism entered the discussion arguing that heterogeneity was the result of the crystallization of styles of production, social relations and domination mechanisms corresponding to different phases of development but coexisting conflictingly within the nation-states. Other regional research problems came to consolidate Latin American Sociology. Marginality became one of the main concerns and soon Liberation Theology was developed in the midst of the Catholic think tanks at work in Santiago de Chile (Beigel, 2011).

FLACSO played a relevant role in offering Masters' degrees in Sociology to many social scientists from different countries who had graduated as historians, philosophers, lawyers and wanted to become sociologists or were already developing the discipline without holding a specific degree. Between 1957 and 1973, its Latin American School of Sociology formed hundreds of graduates, mainly coming from Chile, Argentina, Brazil and Mexico, strengthening the discipline although reinforcing intra-regional academic inequalities (Beigel, 2009a). Other institutions, such as the Latin American Sociological Association (ALAS) and the regional publishing houses (Siglo XXI and Fondo de Cultura Economica) contributed to the circulation of the new regional traditions. Academic awards, such as Premio Casa de las Americas, established in 1960, delineated a regional intellectual prestige that moved in the orbit 
of Cuba and its revolutionary project. This circuit of recognition came into play in legitimizing Sociology as a prestigious discipline, but also as a popular 'vocation' for young militants. In 1967, the Latin American Council for Social Research (CLACSO) was created, and its network of research institutes continued disseminating and expanding these traditions through regional research groups, academic competitions and journals until today.

\section{Latin American Sociology, its History and Laboratories}

Sociology in Latin America has a long history, emerging from different paths of development of social knowledge. On the one hand, within the university field, there were the chairs of Sociology first established at the National University of Colombia (1882) and the University of Buenos Aires (1898). These professors were mostly trained as teachers in history or philosophy, or were lawyers who practiced teaching part-time. A second path developed through social essays, which were often published by newspapers or cultural journals. Finally, a third input came from the State: statistical research and reports put together by technicians from the public bureaus of different ministries.

By the mid-1930s there were dozens of sociology chairs in most of the countries of the region. They existed mainly in the areas of Law, History and Philosophy although always as spaces for complementary teaching. In the technical programs, they were grouped within the sections of 'general culture', the 'culture sciences' or 'science of the spirit' (Beigel, 2010). Graduate education did not develop widely during this time. Wherever it existed, the 'academic doctorate' predominated, with a dissertation as the unique requirement. The great exception was the University of São Paulo, which early on developed the first School of Sociology (1934) and the first graduate program.

As an area of academic research, sociology was differentiated during the 1940s, when the first institutes were created in Mexico, Chile, and Argentina. However, the professionalization of research at the universities was slow and fragmented because higher education was institutionally heterogeneous. The first journals helped in this direction: Sociology, in São Paulo (1939); Mexican Journal of Sociology (1939) from the National Autonomous University of Mexico; the Inter-American Journal of Sociology in Caracas (1939); and the Bulletin of the Institute of Sociology of the University of Buenos Aires (1942). The collections of specialized 
books, edited by the publishing houses Fondo de Cultura Económica, Losada, Abril and Paidós were a key element for the diffusion of local research and preceding translation of foreign Sociology texts.

The relationship between the tradition of Latin American Sociology and the 'national sociologies' followed a specific path according to the country observed, but I do not attempt to cover this here. I will only mention one particular national (Argentinian) staging post that has had a relevant incidence in the construction of a regional founding narrative. I am referring to the main dispute that served to institutionalize the discipline: the opposition between 'scientific sociology' as a program of empirical research and 'chair sociology', which rather refers to social or theoretical essays. These denominations and research styles were linked to the trajectory and interests of two scholars based in Argentina in competition for the newly created professional associations, research and teaching institutions: Gino Germani and Alfredo Poviña.

Neither of them was a 'sociologist' in the strict sense, because they had degrees in other disciplines, philosophy and law respectively. Poviña was in charge of the Sociology chair at UBA and the National University of Cordoba. Germani also wanted to be a 'chair sociologist' but could not attain such a position. As Pereyra (2005) recalls, he aspired to teach at UBA but applied unsuccessfully to two teaching positions at the Faculty of Economics and the Faculty of Philosophy and Literature. This stimulated his argument against 'chair sociologists' and the creation of 'scientific sociology' based on the opposition of social essayism versus empirism, completed afterwards with the pledge for value neutrality and the separation between science and ideology.

This founding narrative based on the confrontation between 'chair sociology' and 'scientific sociology' was critical for the institutionalization of the discipline, and it was manifest in the birth of the Latin American Association of Sociology (ALAS) in 1950. Too attached to Argentinian references, eventually it reflects the evolution of certain internationalized elite groups while diverse alternative expressions of Sociology were at work in many countries (see among others, Guerreiro Ramos in Part One).

Moving beyond this founding myth and searching for the emergence of LAS as a regional tradition, it is imperative to discuss the contribution of the Peruvian José Carlos Mariátegui (1894-1930), who was not a 'scientific sociologist' nor even a 'chair sociologist' but rather the opposite. An autodidact without formal education, he never taught at any university other than the Popular University González Prada, an informal space 
of training courses created for workers during the Peruvian University Reform in 1919. Mariátegui's Seven Essays to Interpret the Peruvian Reality (1928) involves a rich and critical reading of Marxism and an intense engagement with the locally produced knowledge on the history of Peru and Latin America.

His dialogue with Francisco García Calderón, who published Le Pérou contemporain in 1907 in Paris, anticipates the debate between the typical dualism of the sociology of modernization and the Structuralist perspective of the 1960s. Calderón was part of the Société de Sociologie de Paris and participated actively in the journal Revista de América, published in France during the first decades of the twentieth century. According to Mejì Navarrete (2005), he inaugurates the 'national studies' and the dualist interpretation of Peruvian society, opposing a modern coast to a traditional and backward mountain range inhabited by indigenous people (2005: 305). A four-fold shift can be pointed out comparing Calderón and Mariátegui, or Le Perou Contemporain and Seven Essays. First, there was the move from the systemic 'national study' towards the analysis of Peruvian reality as 'the problem of the Indio': from Positivism to Marxism. Second, there was the transition from dualism to structural heterogeneity. Third, came the radical change from the academicist writing practised by Calderón, settled in Paris, to that of Mariátegui from Lima, writing in the midst of social movements. Fourth and finally, was the theoretical and practical move from Peru to Latin America as a historical process and as an intellectual community.

Even if Dependency and the Structural-Historical Method were developed analytically between the 1960s and 1970s, these concerns are rooted in the Latin-American Marxism of Mariátegui. In his diagnosis of the local economic formation, he argued that the Peruvian problems were part of the historical continental process initiated by the Colonial Conquest. An incomplete Independence had given birth to a Republic that coexisted with pre-capitalist relations and servitude; accordingly, capitalism had evolved as an overlapping of ancient and new modes of production: (a) the locally powerful latifundismo (large estates with autonomous rules and production system); (b) the industrial bourgeoisie; (c) the foreign capital investing in mining and other national resources; and, finally, (d) the indigenous communities which subsisted in the mountain ranges with their ancient social and economic traditions. The three expressions of the dominant groups were articulated by the State. This was why Mariátegui argued that the liberal elite and 'national' bourgeoisie were not 
dynamic actors for social change. Socialism and nationalism were, thus, complementary because 'nation' was a project yet to be built (Mariátegui, [1928] 1995).

During his life, Mariátegui not only developed studies of structural social problems but also dedicated a great part of his short life to the creation of a regional circuit for the communication of Indigenists and cultural avant-garde groups throughout Latin America. Spearheaded by his journal Amauta (1926-1930), he created a publishing network that linked nodes in every country of the region (Beigel, 2006a). Mariátegui found his locus and practice in the midst of the scientific reasearch and politics, a hinge where a new focus was furthered, in dialogue with local-regional-European traditions. Because of his precursory vision of structural heterogeneity, his original Latin-Americanization of Marxism and his contribution to the study of the problem of 'race', I argue that this Peruvian essayist should be considered as the founding father of LAS.

In the 1940s important regional studies were published, starting in 1941 with Historia de la sociología Latinoamericana, by Alfredo Poviña; then came Economía de la sociedad colonial. Ensayo de historia comparada de América Latina, by Sergio Bagú (1949) and Materiales para el estudio de la clase media en la América Latina, edited by Theo Crevenna (1950). Germani developed theoretical and methodological studies in his Sociology of Modernization (1969). But the Latin-Americanization of Sociology was given further impetus by the new regional centers, faculties and councils promoted by the United Nations and UNESCO after the Second World War. The creation of the ECLA in 1948 was a fundamental milestone in the development of socio-economic knowledge in the region. It systematized statistical information accumulated in public bureaus during previous decades, and it stimulated the national studies and regional offices, as well as the technical training of the officials of the ministries of finance and planning. The Division of Social Studies, led by José Medina Echavarría, furthered the discussion of the social factors of development in his Consideraciones sociológicas sobre el desarrollo económico de América Latina (Sociological Considerations on Economic Development in Latin America, 1964).

The creation of FLACSO (1957) and the Latin American School of Sociology in Santiago was the result, on the one hand, of Chilean diplomatic proactivity to attract existing foreign aid, and, on the other, of a national State policy aimed at higher education and the development of scientific research. The University of Chile not only provided the 
infrastructure and some teachers, but also largely financed the operation of this center, exceeding the levels of external contributions and eventually taking charge of the institution after the end of UNESCO's sponsorship (Beigel, 2009a). The coups d'état that occurred in Brazil (1964) and Argentina (1966) finally contributed to consolidating the leadership of Chile as a platform for the regionalization of social sciences. Torrents of South American exiles arrived and the regional institutes offered attractive jobs that augured the consecration of a new generation of social scientists. During those years, radicalization was boosted by the famous Camelot scandal (1964-1965) a scientific project funded by the Department of Defense of the United States that aimed to study insurrectionary foci denounced by sociologists as an espionage tool.

In previous studies (Beigel, 2006b, 2010) I have explored the process of academic development that occurred between 1964 and 1973. The regional circuit experienced an exceptional period of productivity, in which new theories and concepts emerged that contributed to the consolidation of indigenous sociological traditions, among them the theories of dependency and the debate on social marginality. These were interdisciplinary debates, traversed by sociology, economics and history. CLACSO played a relevant role as a regional network that favored the development of research groups and performed a determinant role in the regional circulation of the sociological production. During those years Chile became the main laboratory for an endogenous process of knowledge creation, in the context in which this experience generated worldwide attention, first for Christian Democracy, and later for Democratic Socialism.

A series of events completely changed the scenario after the coup d'état in Chile, in September 1973, when President Salvador Allende Gossens committed suicide defending Casa de la Moneda (government building). The universities became a target for the military and the schools of Sociology, Anthropology and Journalism were closed. FLACSO was forced to move to Argentina and some of its students were imprisoned or killed. Many Chilean and foreign social scientists - who had supported Allende - were dismissed, exiled or murdered, and a good many of them saw their work opportunities interrupted in a brutally heteronomous academic field. CLACSO played a decisive role in sustaining the regional circuit by supporting the research institutes in the affected countries and creating networks for the movement of the exiled and persecuted social scientists. Systematic aid programs were created, such as the Relocation Program for Social Scientists (PRCS-CLACSO) and the Refugee Program 
of the World University Service - UK: thousands of Chilean social scientists were transferred to the United Kingdom (Bayle, 2008). Meanwhile, hundreds of private research centers were created with foreign aid and increasingly dependent on external agendas.

Similar military coups quickly occurred in Uruguay and Argentina. The axis of the circuit was moved to Mexico driven by a massive academic exodus escaping from the Southern Cone. According to Agustín Cueva (1988), this situation generated a 'breakthrough' in LAS, which separated the concerns of the sociologists residing in Central America - under the revolutionary environment of the Sandinista Nicaragua (1979) - from the squalid academic fields of South America, decimated by political persecution, unemployment and the absence of academic freedom. In Mexico, heterodox Marxism continued to develop, while in the South critical thinking took refuge in independent academic centers that depended on external aid for their operation. Reflections on democracy, the new social movements, the gender approach and the cultural turn emerged in these years.

In 1989-1991 a great shake-up changed the international configuration and put an end to the world of 'really existing socialism'. The defeat of the Sandinista Revolution through democratic elections in 1990 was a critical local hinge. With the advent of Neo-liberal governments, nation-state came to be considered a 'bad word' and the demise of the two perspectives that had been disputed in LAS until then was decreed: the national approach and class analysis. The research topics of 'critical' sociology began to fade rapidly, along with critical currents of LAS. During the 1990s, LAS survived mostly in the historical research carried out by scholars who were scattered along the continent, had little contact with each other, and achieved the valuable task of dusting off unknown writings and forgotten authors. CLACSO made significant efforts to publish and circulate the accumulation of knowledge produced in the 1960s and 1970s, making this tradition available to young sociologists in a laudable effort to support intellectual history that served as a shelter while awaiting the best times to develop critical social research. While neoliberal-oriented governments were spreading throughout the region and Dependency was losing ground, poverty became one of the main concerns for Sociology. By the end of the twentieth century the regressive effects of those policies highlighted inequality again as the main agenda for LAS, this time along with a broader concern over citizenship. 


\section{Race, Nation and Class Throughout a Sociological Century}

The consolidation of LAS as a research field and regional space was indeed evidenced in the emergence of endogenous traditions based on the historical-structural method, Dependency and Marxism. But also a centennial trajectory can be traced in the sociological studies concerning the trilogy integrated by three analytical categories race, nation and class. There are some homologies with the developments made by these concepts in the US and Europe, along with transnational dialogues, but also deep differences. Class and nation have been very actively present in LAS and several encounters among them can be seen from 1920 onwards. Conversely, race has been characterized by its erratic intervention in social research during the twentieth century. However, its appearance or absence is relevant to understanding old and new regional debates, as I will attempt to explain in what follows.

For many reasons, gender was a subaltern piece in the sociological prism for analyzing inequalities. Firstly, this was because of a structural morphological factor: masculine dominance during the institutionalization and professionalization phases delayed the entrance of women and, accordingly, the emergence of gender studies. The feminization and massification of Latin American universities started around the mid-1950s, thus, the presence of women in teaching and research would increase only after 1960. Secondly, the fact that Marxism and its focus on class was the dominant paradigm also contributed to this direction - women and men were assumed to be equal and the priority was seen to be the class struggle. The process of the de-invisibilization of gender for sociologists was slow and fragmentary. It evolved as an interdisciplinary field deeply linked to the study and the actual evolution of the collective demands of women, which have had a prominent expression in Latin America.

Ciriza and Fernández (1993) argue that the history of the political participation of women includes diverse demands that attempt to include women in citizenship, class struggle and liberation. Three different strands can be observed in the region: the properly called 'feminists', the women formally linked to politics or labor unions, and the more spontaneous women's movements emerging from popular sectors. With diverse demands, points of encounter and mismatches, the feminist movement has developed more consistently since the 1980s, boosted initially by middle-class women linked to Marxism, who confronted the resistance existing in the traditional leftist parties. A broad panorama of the 
so-called 'second wave' of feminism can be found in Vargas's key text (see Part Four).

A singular trajectory can be traced for the theoretical and practical transition from 'women's' to 'gender' studies in Latin America. Cangiano and Dubois (1993) argue that in the same way as white heterosexual women felt outside the field of power in the central countries during the 1960s, black and indigenous Latin American women felt outside of that kind of 'feminist studies'. Marxism was the dominant tradition for local precursors such as Isabel Larguía, Julieta Kirkwood, Heleieth Saffioti and Eva Giberti (see Jelin's key text in Part One). But a particularly original insight into racism, classism and sexism emerged in Brazil in the late 1970s when the myth of 'racial democracy' was finally faced. Immersed in the Unified Black Movement, Lélia González ([1980] 2018) examined the experience of Black female maids (mu'kama o ama de leche) combining Feminism and Psychoanalysis.

Among the spaces that favored feminist dialogue and a regional articulation of local demands were the Feminist Meetings and the UN agency Women, Peace and Development. Some of the most relevant contributions were the studies on dictatorships and the particular marks on bodies along with the studies on the resistance embodied in feminine organizations such as the Madres and Abuelas (mothers and grandmothers) of Plaza de Mayo. It was not until the 1990s that women's studies were firmly tacked on gender studies. The American, Judith Butler had an extensive influence in the expansion of feminist literature in Latin America, together with the arrival of postcolonial debates. Ciriza (2004) analyzes the limits of gender studies that were built through theoretical imports disregarding the local conditions of production and - with higher costs for feminists - without considering the corporeal feature of knowledge itself. The limits of these theoretical imports point then to a local feature of feminism: its materialist perspective and focus on subaltern bodies. More recently, a radical and rooted feminist critique emerged in the midst of the debates on the coloniality of power - struggling against a still resilient indigenous structure of Patriarchy (see Figure I.1).

In sum, during most of the twentieth century gender was a marginal perspective in LAS, although women's demands were an increasing matter of study. Accordingly, the prism for scrutinizing inequality was mainly based on the unstable tripod formed by race, nation and class (RNC), which has a rich history of encounters and disagreements. I am far from even attempting a cartography of this magnitude in this work, but I will 
try to sketch the main landmarks of the crossroads between RNC in order to present the territory in which the more recent inclusion of gender can be observed. As can be seen in Figure I.1, three historical milestones mark the encounters of sociological contributions related to RNC: (1) 1929, (2) 1965 and (3) 2006. In between these dates, bifurcated roads between nation and class prevail, while race transits through an unpaved road mostly mixed with rural issues and studies on peasant movements.

The first RNC encounter was Mariátegui's Thesis on the Problem of Race (1929) and his praxis towards the articulation of the indigenes' demands, national development and socialism (see Part Three). As a convinced Marxist, the Peruvian argued that the Indian's problem was not ethnical, but social and economic: related to land tenure. But unlike the rest of his contemporaries, he believed that indigenes ${ }^{1}$ were the subject of the socialist revolution in Peru, given their historical life in communitary cooperation and the fact that they formed the majority of the population. Noteworthy is his comprehension of the dominant racial claim. 'When on the shoulders of the productive class weighs the harshest economic oppression added to the hatred and vilification of which it is a victim as a race, it is only a matter of clear and simple comprehension of the situation for this mass to rise up as one man to dump all forms of exploitation' (Mariátegui, 1929, see Part Three).

This thesis was prepared for the Communist Conference to be held in Buenos Aires in June 1929, in a particular context. The official discourse existing in the Komintern was to preserve ethnic identity by conferring national autonomy on non-Russian communities that were part of the Union of Soviet Socialist Republics (USSR). On the other hand, the ideological and scientific struggle against biological racism prevented most Marxists from using the concept of race or stimulating its prevalence. During the conference, the Peruvian delegation presented Mariátegui's argument against considering the problem of the Indio as an ethnic-national issue, but instead as an economic problem, the result of the persistence of feudality. For Mariátegui, the solution was Indo-American socialism and the revolution was a national task: to nationalize meant to de-colonize. However, this did not prevent race from playing a relevant role in preparing for this revolution because only activists from the indigenous milieu, sharing a mindset and indigenous language, were able to achieve consent among their peers (Mariátegui, 1929). ${ }^{2}$

A fair balance of Mariátegui's sociological contributions to the problem of race must be considered in light of two processes that marked 


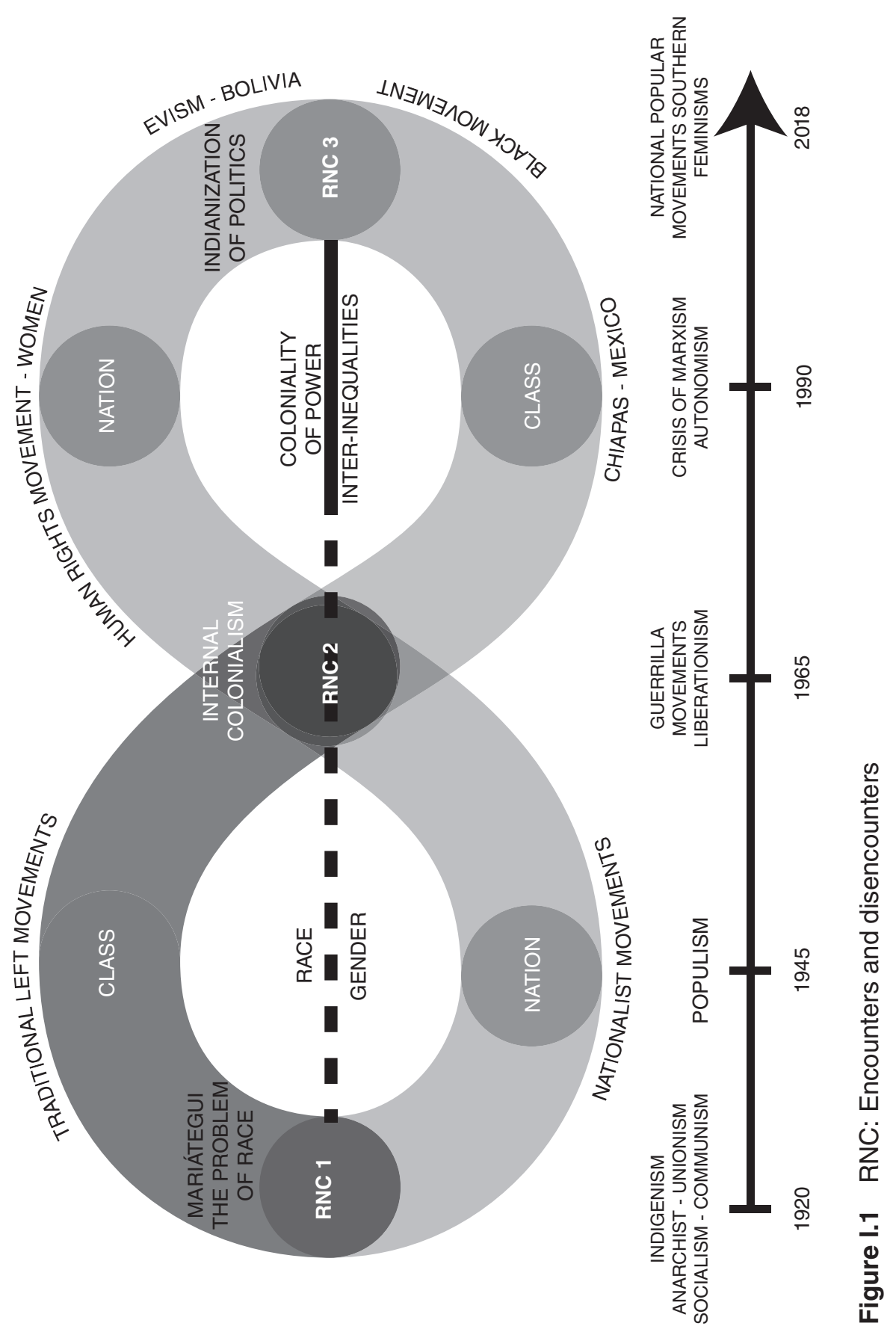


his itinerary: (a) the context of the major social movement in which he took part, Indigenism; and (b) the shift that occurred along his praxis, from Eurocentric to rooted/creative Marxism. Concerning the first context, Indigenism was a cultural and political movement existent from 1870 until 1970, basically concerned with indigenous redemption but featuring an externality from aboriginal communities. As a part of the socialist trend of Indigenism, Mariátegui participated in the urban movement that attempted to change the social conditions of indigenous people, postulating the project of Indo-American Socialism. Race was, for him, a complementary issue, with class and nation being the main axis for defining 'the problem of the indio'. However, and marking a big difference for his times, Mariátegui acknowledged the 'exteriority' of Indigenism. In one of his Seven Essays, he declared that indigenist literature did not offer a true image of the indigenes, because it was still a mestizo literature. "Precisely that is why it is called indigenist and not indigene. An indigene literature is still to come and will arrive in its time. When the Indians themselves are able to produce it' (Mariátegui, 1928 [1995]: 242).

Regarding the second process, in previous studies (Beigel, 2003) I have pointed out that the rooting of Mariátegui's Marxism started in 1925 when he inaugurated his column 'To Peruanize Peru', namely, when he became a sociologist. ${ }^{3}$ His main concern was to build and understand the 'primary problem' of his country. And he was already aware that this 'Peruanization' had taken place within himself. When he returned to Peru in 1923, after four years in Europe, he was despised and considered a 'Europeanizing' intellectual by nativists that rejected Marxism. By 1927, he declared that

Regarding the confluence or alloy of Indigenism and Socialism, nobody attentive to contents and essence can be surprised. Socialism organizes and defines the claims of the masses, of the working class. And, in Perú, the masses - the working class - are four-fifths composed of indigenes. Our Socialism wouldn't be Peruvian - it wouldn't even be Socialism - if it was not based on solidarity, firstly, with the claims of the Indians. In this attitude no opportunism is hidden. Neither artifice, if we give two minutes to a reflection of the meaning of socialism. This attitude is not fake, feigned or clever. It's just socialist. (José Carlos Mariátegui, 'Intermezzo polémico', Mundial, 25 February 1927)

After Mariátegui died, the Stalinization process began to gnaw at the potential of this rooted Marxism. The Komintern promoted a cordon 
sanitaire around Mariátegui's legacy, accusing him of 'populism', and the Peruvian Communist Party adulterated many of his texts in order to canonize him as a Stalinist figure. ${ }^{4}$

As can be seen in Figure I.1, the period 1930-1950 was marked by a disencounter within RNC: the Marxist tradition was inclined to an exclusive focus on class, while populism boosted studies based on the national perspective. Race, for its part, was subsumed by official Indigenist policies, such as the celebration of métissage and the Mexican conversion of Aztecas as a 'national symbol', assimilating indigene communities within the process of the consolidation of nation-states. These nationalist Indigenisms attempted to transform the oligarchic foundations of our societies but eventually collaborated in the prevalence of colonial relations. Meanwhile, Indian and Black communities resisted assimilation by different means.

During the 1940s, RNC categories were developed in separated paths, in a sort of division of labor: Sociology was more concerned with class stratification, while Anthropology addressed the racial issues. After the genocide and the catastrophic consequences of the Second World War, the concept of 'race' was seriously revised in the European social sciences and replaced by the category of 'ethnic group'. The elimination of the notion of race, based on the scientific evidence regarding the nonexistence of biological differences, was believed by many as a way of evaporating racism itself. One of the first proposals for addressing ethnic discrimination in the public sphere was the idea of defining 'minorities' and granting rights for them. An obvious problem emerged when adopting this type of policy in countries where Blacks and Indians were the majority of the population - the simple observation that had boosted Mariátegui's indigenization of Marxism.

Latin American social sciences were not absent in this debate, being present firstly within the new international agencies and later through the concept of 'internal colonialism'. The Brazilian 'racial democracy' was at the center of interest within the unique ambit that became relatively 'international' in the debate towards a consensual, anti-racist, definition of 'race': the United Nations Education, Science and Culture Organization (UNESCO). Several studies (Chor Maio, 2007; Dumont, 2010; Beigel, 2013) have observed that during the 1950s, the Latin American governments played a relevant role within this Organization, and especially Brazil, during the directorship of the Mexican Jaime Torres Bodet (1948-1952). A board of 
experts was created with the aim of publishing a declaration to sanction racial discrimination. These declarations were the basis for a campaign developed by UNESCO against the apartheid regime in South Africa and racial prejudice in the United States. According to Chor Maio, Brazil was considered as a case of 'harmonious' racial relations and ended up as a key to the anthropological discussion in the boards of experts - four of the nine experts invited to the first meeting in Paris (1949) were Brazilian and others had carried out fieldwork in Brazil. A large group of ethnologists who afterwards would became big names in Sociology, History and Anthropology had arrived in the country in the late 1930s: Claude Lévi-Strauss and Roger Bastide, among others.

In 1950, the UNESCO Division of Racial Studies was created, under the direction of Alfred Métraux, becoming a 'pro-Brazil lobby group' (Chor Maio, 2007: 193) within the Department of Social Sciences, by that time under the direction of the Brazilian anthropologist Arthur Ramos. In 1951-1952, Métraux organized a project to study racial relations in Brazil with Roger Bastide, Florestan Fernandes and a group of students from the Universidade de São Paulo in charge of carrying out a survey. Among the students were Octavio Ianni and Fernando Henrique Cardoso. The report was delivered the following year and the results pointed to the existence of racism and its connection with poverty (The UNESCO Courier, 1952). Surprisingly, this report contradicted the ideal of a Brazilian 'inter-racial paradise', all of which certainly divided local scholars and hastened the withdrawal of Métraux from the Organization.

The next encounter of the RNC conceptual trilogy came during the 1960s, a period of politicization and radicalization in Latin American societies. A broadening of the regional perspective took place through the dialogue with decolonization movements in Asia and Africa, in a new forum christened as 'tercermundismo' after the Bandung Conference of 1955. This context had a particular incidence in the social sciences, and the idea of 'liberation' became the soil for the connection of social demands on class, nation and race. Nelson Mandela's struggles against apartheid, the civil rights movements in the United States and Frantz Fanon's writings circulated profusely in Latin America. Solidarity with the Black movement and the Algerian Revolution was in fact extended but scarcely connected to the demands of Blacks and Indians in Latin America. This state of social movements was reflected in the late interest for race in LAS. A distorted dejá vú from Mariátegui's RNC argument was still dominant: class was considered the primary struggle, while racism would be 
destroyed as a result of the socialist revolution, which, in time, was understood as a national form of liberation from Imperialism.

In this context, a second confluence on RNC can be found in the concept of 'internal colonialism' developed by Pablo González Casanova and Rodolfo Stavenhagen (see Part Three). Both authors were involved in debates and had conceptual differences, but the novelty was to observe the persistence of colonialism through inter-ethnic relations within the nation-states. For Stavenhagen, internal colonies were marked by the cultural differences between two sectors of the population. In this case, race appeared in the center of the conceptualization, but its significance was more related to the prevailing notion of ethnic group. On his part, González Casanova argued that internal colonialism included the economic, social and cultural dimensions of domination. The indigene communities were seen as nations that are colonized by the nation-state and suffer a kind of subalternity similar to colonialism or neocolonialism. According to him, they inhabit in a territory without a government of their own. They speak a language and have a culture different from the legitimate 'national' language and culture. They are in a situation of inequality in relation to the elites of the dominant ethnicity who consider this colonized race as inferior or, in the frame of assimilation, as an inert symbol of national identity (González Casanova, [1969] 2006).

Even if the concept of internal colonialism emphasized the racial perspective, it was still hanging between 'nation' and 'ethnic group'. But the main success of this RNC encounter was to overthrow the idea of assimilation as a legitimate course driven by the State - whether or not this was imagined as a 'popular' State. As would be clear afterwards, coloniality was imposed through the naturalization of racial difference and social inequality, but class was the dominant concern throughout rural and urban workers' movements during the process of modernization in Latin America until mid-twentieth century. Whenever class was articulated with the question of nation, it was believed that nationalization under a socialist project was the path for de-colonization. The project of National Liberation or Independence was compatible with the classism existent in these traditional movements, while ethnicity was considered a subordinated matter, dependent on class struggle. Experiences such as the Bolivian Revolution of 1952 tended to consider the Indian as a peasant, with land tenure as their main social problem. Indigenists' 'externalism' was still at work. Accordingly, during the radical phase of the 1960s, perspectives on class 
and nation found a locus within liberationism, but race and gender still remained as marginal perspectives.

An exception to this path can be found in Brazil, where race relations had been a sociological concern since the 1950s, starting with the UNESCO study mentioned above. According to Araujo Guimarães (see the Introduction to Part Three), Florestán Fernandes came to confront a pattern of accommodation that was interpreted as a 'color gradient', diluting the racial dimension of inequalities, perhaps as the diachronic presence of a past amid capitalist expansion. The sociological contribution of Fernandes and other Brazilian sociologists counteracts the observations made by Bourdieu and Wacquant (1998) in the polemical article 'On the Cunning of Imperialist Reason' - in which they denounced the imposition of an American notion of race into the Brazilian academic field. Racial studies have a long and rooted history in Brazil and racism was far from being solved by the myth of 'racial democracy', as would be evidenced in the next years. ${ }^{5}$

The course of the sociological analysis of race would make a radical turn only by the end of the twentieth century. A silent but consistent process of incarnation of ethnicity was taking place in the local Indian and Black movements but its major manifestations would become regionally visible by the 1990s with the creation of the Pachakutik political parties in the Andean countries, the 1994 insurrection of Chiapas, and the Brazilian Black movement. In previous work (Beigel, 2005b) I examined the process by which ethnicity became a relevant factor of auto-identification within indigenous movements, after being sealed by the communist tradition or misrepresented by urban/mestizo indigenist literature. The idea of an illuminated avant-garde supposedly embodied by leftist parties but generally composed of bourgeois intellectuals contributed to this blindness. A particular form of de-alienation of negative identities was taking place, expressed in the Andean zone, for example in public campaigns such as Ecuador's graffiti 'Amo lo que tengo de Indio' [I love what there is of Indio in me].

Well now, a critical point should be posed here: was the emergence of race as an organizing principle of identification something new, or had it rather been invisible to the social sciences and the leftist political parties? Indeed, it was not really a new process of identification but a combination of ancient and recent memories of subalternity. In which form were these memories re-actualized and by which means was race incarnated in the Latin American social movements is the subject of Part Four of this 
volume (see the introductory chapter by Bringel). Here I will only point out the fact that the agenda of LAS has evolved behind the morphological changes observed in the social movements.

Segato has argued that until the beginning of the twenty-first century it was rare in Latin America to find reports on the color of the poor, people in prison or victims of police abuse. This was the effect of the 'ethnocide metissage' - a forced cancellation of the 'non-white' memory. Race was mostly treated as a cultural feature but not as part of the unequal condition of the population, even if it is a mark of subalternity and domination present since the Conquest (Segato, 2010). The Indigenist movement and State Indigenism contributed greatly in this direction: indigenous communities were analyzed as 'peasants' and Afro-descendants were seen as 'integrated' into an illusionary but persistent racial democracy (Wade, 2017).

As a result of the emergence of new Indigene/Black movements by the mid-1970s the 'prosecution' of Indigenism was fulfilled while research on race and gender entered increasingly into the regional sociological agenda. Eventually, it was after the collapse of communism that race came to the forefront. At first sacrificing the nation-class binomial, it was boosted by postcolonial studies and the belief that Latin-Americanism and Dependency Analysis were responsible for a now old perspective centered in the 'nation-state' as a unit of analysis and 'class' as a central principle of identity. The novelty was that the category of race became the main axis for the comprehension of domination and social inequality in the capitalist world-system. These debates integrated a dialogue on Eurocentrism that was already taking place in other spaces in the newly baptized 'Global South'. In fact, during these years, class was rephrased into the struggle between South and North, while the displacement of the category of 'nation' was fulfilled. Race gained increasing interest in social research and has been a central issue for intersectional feminism, de-colonial perspectives and studies on inequality.

Actively part of this debate, but from a different side, Quijano (1992) developed his transition from Dependency to Coloniality, articulating class and race into a theory of domination. He argued that colonialism is a historical phenomenon that starts with the Conquest of America, Asia and Africa by the European powers and ends with de-colonization revolutions that took place at the beginning of the nineteenth century. Latin America was the first entity/historical identity of the current colonialmodern world system. It was constituted as the 'Occidental Indies', 
the original space and beginning of a new pattern of power. It was the place of the first classification of the survivors of the colonial genocide as indios - an 'indigenization' expressed as a 'racialization' that includes at the same time class and racial subalternity. Coloniality thus, had proven to be, in the last five hundred years, more profound and lasting than colonialism (Quijano, 2010). This new RNC trilogy fed by postcolonial studies and Quijano's 'coloniality of power' reinforced the place of race-class as causal relations to explain inequalities, but tended to leave aside the national question typically central in the 1960s (see Figure I.1).

After the victory of Evo Morales in the presidential elections of Bolivia (December 2005), a new type of government headed by an Aymaran leader changed the agenda of the social sciences. The 'political instrument' that led Morales to power, the Movement for Socialism (MAS), was built in the midst of cocalero unionism and the massive demonstrations in defense of water and gas as natural (national) resources against transnational companies. These two forms of traditional struggle, historically embodied in syndicalism (class) and anti-foreigner movements (nation), arrived now with a sense of novelty. The growth of MAS and the social movements was based on the defense of traditional knowledge, communal justice and indigene organizations.

In 2009 the Bolivian Constitution was completely reformed defining the country as pluri-national and recognizing all indigene nations and languages as official. In parallel, the Bolivian nation was affirmed and a program of nationalizations was performed. A broader relevant change completed the new scenario: the resurrection of Latin-Americanism, starting with the regional initiatives of a pool of presidents such as Hugo Chávez, Néstor Kirchner, Lula da Silva and Evo Morales. In a research agenda with an already consolidated concern for race and class, nation came back on the scene, stirring up postcolonial theories that had based their reflections on the disappearance of nationalism as a collective identity. Several critiques (Svampa, 2016; Stefanoni, 2010) were made of the developmentalist path used by Morales and the limits of de-patriarchalization, but undoubtedly a relevant morphological change took place in the Bolivian social milieu. To be an 'Indio' was considered negative and it was a symbol for subalternity in the history of the country. Now, an indianization of politics took place: to be an Indio meant having a form of relevant social capital impacting rapidly on the composition of the bureaucratic elites. Accordingly, the 
Bolivian experience has been a decisive laboratory for a new lens onto inequality, this time reinforcing a new RNC trilogy. Meanwhile, Southern feminisms seem to be preparing the ground, or underground, for the emergence of a RNCG (Race, Nation, Class, Gender) sociology eager to rise.

\section{What is 'Critical' in LAS?}

The founding narrative based on the opposition between 'chair' and 'scientific' sociology was consolidated by Rolando Franco in his well-known article '25 Years of LAS: A Balance', published in Revista Paraguaya de Sociología in 1974. The aim was to discuss 'scientific sociology' in order to argue for the validity of 'critical sociology', as the third and contemporary phase of LAS (Franco, 1974). In Spanish, 'critical' meant the contrary to the former program of 'value neutrality', launched by Germani, and a call against the separation between science and ideology. In English, it would be accurate to say that it was critical for this generation of sociologists to engage with politics in order to question established values and unjust structures. In this act, by reinforcing 'critical' sociology, Franco also canonized 'chair', 'scientific' and 'critical' as the three phases of LAS.

The identification between these three phases and the process of institutionalization of national sociologies in the region also contributed to establishing this founding narrative. However, after the process of de-institutionalization experienced in South America and the dismantling of the regional circuit with an axis in Chile, this periodization seemed truncated. More recently, a few studies revised the history of LAS. Svampa (2008) and Roitman Rosenmann (2008) proposed a periodization based more on the central debates of each stage: modernization, dependency/exploitation, dictatorship, democracy and globalization. From a de-colonial perspective, Martins (2012) argues that the constitutive tension of LAS is in the dichotomy between coloniality and anti-coloniality. The first stage would feature a post-independency social thought until 1950, followed by a critical postcolonialist sociology - in his view too attached to Eurocentric perspectives and not finally in breaking from the previous phase. Critical Sociology would have arrived in Latin America in the 1990s, along with the displacement of the center-periphery focus and the new perspectives on discourse analysis. In particular, Martins argues that Dependency Analysis exhibited its limits to explain the relevance of 'cultural' and post-geographical factors in the global era (Martins, 2012: 34). 
This periodization attempts to discredit the founding narrative by pushing critical sociology to contemporary times. However, critical sociology is not a phase nor a particular theoretical argument, but a way of practicing the discipline. As Svampa (2008) argues, it is a type of amphibian sociology, in-between academic knowledge and militant engagement - starting with Mariátegui, who was not a 'chair' sociologist and perfectly fits under the label of 'critical' sociologist, with one foot in the social essay and the other in the Indigenist movement. This persistent, historical and regional feature of LAS is radically different from Burawoy's (2005) 'critical' and 'public' sociology. Regarding the first, this regional sociology is not merely academic but involved in social movements. In relation to the second, critical LAS is 'public' - not by intervening in the media debates, but because of its commitment to a particular type of public intervention rooted in the intellectual field. In this sense, critical LAS is not attached to the limits of conceiving social actors as 'audiences' and thus centering its intervention on the mass media. On the other hand, it features by multiple styles of production, combining research and political intervention. More amphibious than academicist and more critical than policy oriented, LAS is a long-standing international platform for global debates.

Although international from birth, the global projection of LAS has been limited by two causal factors on different levels: firstly, the fact that most of its contributions were published in Spanish or Portuguese; and, secondly, the fact that this old regional circuit of recognition has been increasingly subordinated to the mainstream circuit and its high impact on circulation. This volume is aimed precisely at making available our sociological traditions in order to drive global and South-South dialogue. The project was conceived in a workshop held in Mendoza, in 2012, where the scientific committee discussed the difference between 'classics' and 'key texts'. The idea was to broaden the circulation of Latin American Sociology as a tool for today's analysis of our tumultuous world, and not just to translate classical texts that may have already circulated in English. Instead of thinking about regionally or globally canonized texts, this workshop stressed the fact that the volume should provide an insight into local contributions to current global debates.

It was also considered relevant to show our diversity in terms of subregional traditions - preventing the replaying of existing intra-regional asymmetries, observing gender balance and including authors from as many countries as possible. It was not easy to achieve national diversity under the limits of a single book, but we reached a basic balance. Most 
of the authors of the key texts have produced their complete work while living and working in Latin America. Only three authors have spent part of their lives in the North (Escobar, Laclau and O'Donnell) due to exile or settlement abroad. In the cases of Laclau and O'Donnell, they decided to return to their homeland in Buenos Aires in the last part of their trajectory. Escobar currently works as a professor partly in the US and partly in Colombia.

Gender balance was a more difficult task. The high levels of masculinization registered in LAS until 1970 cannot/should not be compensated for by an anthology. We decided to give gender debate a relevant space in Parts One to Four and to include a text by the sociologist Suzy Castor in Part Five - whose contribution to the debate on nation-state building has had an even smaller circulation given the fact that she is Haitian, a woman and wrote in Créole or French. The fairest balance was achieved in the six introductory studies, with three written by men and three by women.

Finally, this book is organized in five sections, each one is dedicated to a thematic debate: (1) Founding problems; (2) Historical and contemporary debates; (3) Social structure and inequalities; (4) Identities, actors and social movements; and (5) State, society and politics. The structure of all the parts includes an introductory study, with a selection of key texts followed by brief Comments presenting basic bio-bibliographical data on the author's trajectory.

\section{Notes}

1. There are serious translation problems when referring to Indigenism, indigeneity and indigenous people or 'Indios' (as used historically by the actors) that must be considered. The concept of indigenous in English remits to autochthony and to native people. In Latin America 'Indigena'/indigenes refers to aboriginal communities that were called Indios by the colonizers during the conquest. For its part, Indigenism is a political and cultural movement developed mainly by middle-class urban mestizos, creating an external representation of the Indios with no participation of those communities. Indigenism as a movement and as a project can be considered cancelled since the mid-1970s when the indigene movements throughout the region started creating their own political organizations to intervene directly in politics. During the 1920s 'Indio' was extensively used to refer to indigene communities. Currently 'indigena/movimiento indigena' is the concept academically used in Spanish to refer to aboriginal people. I have chosen to use the term "indigenes" to translate the latter, preserving "indigenous" for meaning autochtonous or rooted.

2. In several parts of his writings, Mariátegui uses the word Race in opposition to racist uses, advocating in favor of an indigene national project. When he founded his noted journal Amauta (Savant in Quechua) he said that this title was an expression of his 
'adherence to the Race, his homage to Incaism' (Mariátegui, 1926:1). This alternative concept of race has been in force in the last decades within Latin American movements, and the polemic use by Mariátegui is still interesting for current sociological and anthropological debates.

3. The column titled 'To Peruanize Peru' ('Peruanizar al Perú') was published in the journal Mundial from September 1925 until 1930. The first article was titled 'El rostro y el alma del Tawantinsuyu' [Face and Soul of Tawantinsuyu], Mundial, Año VI, n 274, 11 September 1925.

4. The return to Mariátegui's texts in Latin America came many decades later, particularly in the 1980s when he became a relevant figure in the debates of the South American exiles in Mexico, together with the renewed interest in Gramsci. Indeed the trajectories of these two intellectuals have similar paths which are incredibly close because of the short and harsh lives they lived, the fragmented writings they left and the issues they developed. But no 'influences' can be pointed out (Beigel, 2005a).

5. For a discussion on Bourdieu and Wacquant's article, see Beigel (2009b).

\section{References}

Bagú, Sergio (1949) Economia de la sociedad colonial. Ensayo de historia comparada de América Latina [Economy of Colonial Society. Essay on Comparative History of Latin America]. Buenos Aires: El Ateneo.

Bayle, Paola (2008) 'Emergencia académica en el Cono Sur: el programa de reubicación de cientistas sociales (1973-1975)', Iconos. Revista de Ciencias Sociales, 30: 51-63.

Beigel, Fernanda (1998) 'Identificados con un proyecto', Anuario Mariateguiano, X(10): 91-106.

Beigel, Fernanda (2003) El itinerario y la brújula. El vanguardismo estético-político de José Carlos Mariátegui. Buenos Aires: Biblos.

Beigel, Fernanda (2005a) 'Una mirada sobre otra: el Gramsci que conoció Mariátegui', Estudos de Sociología, UNESP, 10(18/19): 23-49.

Beigel, Fernanda (2005b) 'Las identidades periféricas en el fuego cruzado del cosmopolitismo y el nacionalismo', Pensar a Contracorriente, Concurso Internacional de Ensayos, Tomo I, La Habana: Editorial de Ciencias Sociales, pp.169-199.

Beigel, Fernanda (2006a) La epopeya de una generación y una revista. Las redes editoriales de José Carlos Mariátegui en América Latina. Buenos Aires: Biblos.

Beigel, Fernanda (2006b) 'Vida, muerte y resurrección de las teorías de la dependencia', in F. Beigel et al., Crítica y teoría en el pensamiento social latinoamericano. Buenos Aires: CLACSO, pp. 287-326.

Beigel, Fernanda (2009a) 'La FLACSO chilena y la regionalización de las ciencias sociales en América Latina (1957-1973)', Revista Mexicana de Sociología, 71(2): 319-349.

Beigel, Fernanda (2009b) 'Sur les tabous intellectuels: Bourdieu and academic dependence', Sociologica, 2-3.

Beigel, Fernanda (2010) Autonomía y dependencia académica: Universidad e investigación científica en un circuito periférico. Chile y Argentina (1950-1980). Biblos: Buenos Aires. 
Beigel, Fernanda (2011) Misión Santiago. El mundo académico jesuita y los inicios de la cooperación internacional católica. Santiago de Chile: LOM.

Beigel, Fernanda (ed.) (2013) The Politics of Academic Autonomy in Latin America. London: Ashgate.

Bourdieu, Pierre and Wacquant, Löic (1998) 'Sur les ruses de la raison impérialiste', Actes de la Recherche en Sciences Sociales 121-122: 109-118.

Burawoy, M. (2005) 'For public Sociology', American Sociological Review, 70(1): 4-28.

Cangiano, M. and Dubois, L. (1993) 'De mujer a género: Teoría, interpretación y práctica feminista en las ciencias sociales', in M. Cangiano and L. Dubois (eds), Teoria, interpretación y práctica feminista en las ciencias sociales. Buenos Aires: Centro Editor de América Latina, pp. 7-16.

Chor Maio, Marcos (2007) 'Un programme contre le racisme au lendemain de la Seconde Guerre mondiale', 60 ans d'Histoire de l'UNESCO. Paris: Maison de l'UNESCO, pp.189-197.

Crevenna, T. (1950) Materiales para el estudio de la clase media en America Latina. Washington: Union Panamericana.

Ciriza, Alejandra (2004) 'Notas sobre los límites de la importación teórica. A propósito de Judith Butler', El rodaballo, 15: 58-60.

Ciriza, Alejandra and Fernández (1993) 'Las mujeres y su inclusión en las prácticas políticas', in A. Roig (ed.), Argentina del 80 al 80. Mexico: UNAM, pp. 157-182.

Costa, Sergio (2018) 'The research on modernity in Latin America: Lineages and dilemmas', Current Sociology, published online, 5 November, DOI: 10.1177/001139211 8807523.

Cueva, Agustín (1988) 'Sobre exilios y reinos. (Notas) Críticas sobre la evolución de la sociología sudamericana', Estudios Latinoamericanos, Mexico: CELA-UNAM.

Dumont, Juliette (2010) 'From intellectual cooperation to cultural diplomacy: the Brazilian and Chilean experience (1918-1946), Colloque 'Impacts: Does Academic Exchange matter?', Austrian-American Educational Commission(Fulbright Commission),Vienna, 18-19 November.

Franco, Rolando (1974) '25 años de Sociología Latinoamericana', Revista Paraguaya de Sociología.

Germani, G. (1969) Sociología de la Modernización. Estudios teóricos, metodológicos y aplicados a América Latina. Buenos Aires: Paidós.

González, Lélia ([1980] 2018) 'Racismo y sexismo en la cultura brasileña' in B. Bringel, and A. Brasil Jr. Antología del Pensamiento crítico brasileño contemporáneo, Buenos Aires: CLACSO, pp. 565-583.

González Casanova, Pablo ([1969] 2006) El colonialismo interno, in Sociología de la explotación. Buenos Aires: CLACSO, pp. 185-205.

Heilbron, Johan (2015) French Sociology. New York: Cornell University Press.

Mariátegui, José Carlos (1926) Presentación de Amauta, Amauta, 1: 1.

Mariátegui, José Carlos ([1928] 1995) Siete ensayos de interpretación de la realidad peruana. Lima: Sociedad Editora Amauta.

Mariátegui, José Carlos (1927) 'Intermezzo polémico’, Mundial, Feburary 25.

Mariátegui, José Carlos (1929) 'El problema de la raza’, Amauta, 25: 69-80. 
Martins, Paulo H. (2012) La decolonialidad de América Latina y la heterotopia de una comunidad de destino soldaría. CICCUS.

Medina Echavarría, J. (1964) Consideraciones sociológicas sobre el desarrollo económico en América Latina. Buenos Aires: Solar/Hachette.

Mejía Navarrete, Julio (2005) 'El desarrollo de la sociología en el Perú. Notas introductorias', Sociologias, Porto Alegre, 7, (14): 302-337.

Narvaja de Arnoux, Elvira (2008) El discurso latinoamericanista de Hugo Chávez. Buenos Aires: Biblos.

Pereyra, Diego (2005) International Networks and the Institutionalisation of Sociology in Argentina (1940-1963), Doctoral Dissertation: University of Sussex at Brighton.

Poviña, A. (1941) Historia de la Sociología Latinoamericana. Mexico: Fondo de Cultura Económica.

Quijano, Aníbal (1992) “"Raza”, "Etnia” y “Nación” en Mariátegui: Cuestiones Abiertas', in José Carlos Mariátegui y Europa: El otro aspecto del descubrimiento. Lima: Ed. Amauta. pp. 167-188.

Quijano, Anibal (2010) “'Bien Vivir” para Redistribuir el poder. Los pueblos indígenas y su propuesta alternativa en tiempos de dominación global'. In Informe 2009-2010 Pobreza, desigualdad y desarrollo en el Perú. Lima: Oxfam.

Roitman Rosenmann, Marcos (2008) Pensar América Latina. El desarrollo de la Sociología Latinoamericana. Buenos Aires: CLACSO.

Sapiro, G. (2017) Los intelectuales: profesionalización, politización, internacionalización. Eduvim: Cordoba.

Segato, Rita (2010) 'Los cauces profundos de la raza latinoamericana: una relectura del mestizaje', Crítica y Emancipación, Año II (3): 11-44.

Stefanoni, P. (2010) 'Bolivia después de las elecciones: ¿a dónde va el evismo?', Nueva Sociedad 225.

Svampa, Maristella (2008) 'Reflexiones sobre la sociología crítica en América Latina y el compromiso intelectual', Cambio de época. Buenos Aires: Prometeo, pp.19-41.

Svampa, Maristella (2016) Debates Latinoamericanos. Indianismo, Desarrollo, Dependencia, Populismo. Buenos Aires: EDHASA.

The UNESCO Courier (1952) 'Informe sobre las relaciones raciales en el Brasil', Vol. 8/9.

Wade, Peter (2017) 'Racism and race mixture in Latin America', Latin American Research Review, 52 (3): 477-485. 